\title{
Cross-Border Mergers and Acquisitions by Emerging Market Firms: A Comparative Investigation
}

Ping Deng

Cleveland State University, p.deng@csuohio.edu

Monica Yang

Adelphi University, yang2@adelphi.edu

Follow this and additional works at: https://engagedscholarship.csuohio.edu/bus_facpub

Part of the Business Commons, and the Law Commons

How does access to this work benefit you? Let us know!

\section{Publisher's Statement}

NOTICE: this is the author's version of a work that was accepted for publication in International Business Review. Changes resulting from the publishing process, such as peer review, editing, corrections, structural formatting, and other quality control mechanisms may not be reflected in this document. Changes may have been made to this work since it was submitted for publication. A definitive version was subsequently published in International Business Review, 24, 1, (2015); http://dx.doi.org/10.1016/j.ibusrev.2014.07.005

Original Published Citation

Deng, P., \& Yang, M. (2015) Cross-Border Mergers and Acquisitions by Emerging Market Firms: A Comparative Investigation. International Business Review, 24, 1, pp. 157-172.

This Article is brought to you for free and open access by the Monte Ahuja College of Business at EngagedScholarship@CSU. It has been accepted for inclusion in Business Faculty Publications by an authorized administrator of EngagedScholarship@CSU. For more information, please contact library.es@csuohio.edu. 


\title{
Cross-border mergers and acquisitions by emerging market firms: A comparative investigation
}

\author{
Ping Deng ${ }^{\mathrm{a}, *}$, Monica Yang ${ }^{\mathrm{b}, 1}$ \\ ${ }^{a}$ Monte Ahuja College of Business, Cleveland State University, Cleveland, $\mathrm{OH} 44115$, USA \\ ${ }^{\mathrm{b}}$ Robert B. Willumstad School of Business, Adelphi University, Garden City, NY 11530, USA
}

\section{Introduction}

In the last two decades, outward foreign direct investment (OFDI) from emerging economies has grown massively and has become an important engine for the global economic growth. According to the World Investment Report 2014, emerging economies accounted for more than one third of global OFDI flows in 2013 and China, the largest source of OFDI among emerging countries, continued to maintain its position as the third largest investor in the world, reaching a new record of $\$ 101$ billion (UNCTAD, 2014). On top of that, the majority of OFDI from emerging economies is created through cross-border mergers and acquisitions (M\&As), a fast track of international growth strategy that is driven by diversified objectives. Through aggressive international acquisitions in a wide range of industries, emerging market firms (EMFs) have achieved important strategic objectives,

\footnotetext{
\# The order of authorship is listed alphabetically and both authors contribute equally.

- Corresponding author. Tel.: +1 216875 9793; fax: +1 2166874708 .

E-mail addresses: p.deng@csuohio.edu, pdeng8@hotmail.com (P. Deng), yang2@adelphi.edu (M. Yang).

1 Tel.: +1 516877 4649; fax: +1 5168774607 .
}

such as the acquisition of technology, brand names, and natural resources (Deng, 2013; UNCTAD, 2014). As EMFs continue a steady upward trend in OFDI and cross-border M\&As in particular, understanding of the driving forces and strategic implications of their international investment deserves more scrutiny and discussion.

In recent years, an increasing number of research has examined location determinants of OFDI by EMFs (e.g., Jain, Hausknecht, \& Mukherjee, 2013; Ramasamy, Yeung, \& Laforet, 2012). However, there is a research gap in exploring this important topic from a comparative approach. The extant literature on OFDI and particularly cross-border M\&As by EMFs is not only under-studied but also has three major limitations. First, among the relatively few comparative studies, researchers have ignored resource dependence theory (RDT), one of the dominant theoretical rationales explaining why firms engage in M\&As (Hillman, Withers, \& Collins, 2009). This important theoretical omission might well explain why extant comparative literature on locational determinants of crossborder M\&As from emerging economies tends to be confusing and inconsistent. Given its focus on firm dependence on external environments to stabilize resource exchanges (Pfeffer \& Salancki, $1978,2003)$, RDT could provide a pertinent theoretical framework to clarify conflicting results. Second, comparative studies have been suggested as a useful approach to test or generalize Western 
findings and develop theories from emerging economies, but have rarely been attempted in examining cross-border M\&As by EMFs in different contexts (Deng, 2013; Kothari, Kotabe, \& Murphy, 2013). By distinguishing M\&A projects initiated by EMFs in different types of target markets, we could advance mainstream theory (e.g., RDT) by finding which research involving emerging market M\&As is context specific, context bound, or context free (Child, 2009; Tsui, 2004; Xu \& Meyer, 2013). Third, the samples are based mainly on one single country (e.g., China or India) and the empirical results are mixed. Therefore, it is questionable whether the results of cross-border M\&As by companies from one emerging market can be generalized to other EMFs.

In terms of research setting, we scrutinize M\&A deals by companies from nine major emerging economies (Brazil, China, India, Indonesia, Mexico, Russia, South Africa, Thailand, and Turkey) in developed and developing countries from 2000 to 2012 (see Table 1 ). We select these countries since they are ranked highest among all emerging countries in the number of crossborder M\&As. In so doing, we contribute to extant literature in three ways. First, beyond the dyadic interdependence between EMFs and host markets, this study also emphasizes a triadic relationship by introducing host government effectiveness, an important but less considered institutional component in the resource dependence literature, as a boundary condition of the resource dependence logic of M\&As. By examining the moderating effects of government effectiveness in global settings, we may offer new insights into RDT. Second, equipped with an explicit theoretical framework (i.e., RDT), our study endeavors to provide a first attempt to systematically compare cross-border M\&As by EMFs in different contexts. Due to substantial differences between developed and developing countries with regard to economic development, institutional environments, corporate governance, and domestic capital market (Hoskisson, Wright, Filatotchev, \& Peng, 2013: Xu \& Meyer, 2013), it is critical to investigate the investment motives of EMFs in each host environment, thus having a systematic understanding of the contextual variables behind the M\&A motivations by EMFs. Third, given that extant comparative studies were based mainly on samples from one single country (e.g., China) and researchers tend to generalize the results to other EMFs, we contribute by discovering whether our results derived from much broader samples of EMFs could be generable to Chinese firms or vice versa.
The rest of the paper is organized as follows. The next section reviews the resource dependence perspective on location determinants of cross-border M\&As by EMFs, followed by the hypotheses of the paper. The third section sets out the research methods and data of the study. The results and findings are reported in the fourth section. Theoretical and practical implications as well as future research directions are provided in the last section.

\section{Theoretical background and hypothesis development}

Among numerous research themes of cross-border M\&As a central research question is: "What attract cross-border M\&As from other economies?" As emerging economies are becoming a critical force in reshaping global business landscape, researchers have explored this crucial question particularly involving EMFs (e.g., Antkiewicz \& Whalley, 2007; Buckley, Forsans, \& Munjal, 2012; Wang, Hong, Kafouros, \& Boateng, 2012). However, few empirical studies employ comparative approach to examining the antecedents that attract international acquisitions by EMFs in different types of markets (Jain et al., 2013; Yang, 2012). As shown in Table 2, among the nine articles that adopt a comparative approach, most of them compare the location determinants of OFDI (including cross-border M\&As) by EMFs in developed countries as opposed to developing countries; they use samples largely from one single country (e.g., China or India) and the results are inclusive. Some found that the disparity in attracting OFDI exists between developed and developing markets (e.g., Kang \& Jiang, 2012), whereas others found no difference (e.g., Duanmu, 2012). Likewise, in the three comparative studies of Chinese and Indian OFDI, the results are equally confusing. Therefore, it is imperative to embrace samples involving much more emerging economies and find out whether the results based on samples from one single country could be generalizable to other EMFs and how those factors attracting cross-border M\&As from EMFs in developed markets are the same as (or different from) those in developing markets.

More importantly, extant comparative studies on cross-border M\&As by EMFs tend to lack a systematic theoretical perspective (see Table 2). The lack of a clear theoretical framework may explain why the empirical results of existing studies are largely confusing or inconsistent. Given its focus on firm dependence on external

Table 1

List of target countries (developed vs. developing markets) in the sample.

\begin{tabular}{|c|c|c|}
\hline Countries of acquiring firms & Target county (Developed market) & Target country (Developing market) \\
\hline Brazil & Canada, France, Italy, Netherlands, Portugal, Spain, UK, USA & Argentina, Chile, Columbia, Mexico, Peru, Uruguay \\
\hline China & $\begin{array}{l}\text { Canada, France, Germany, Italy, Japan, Netherlands, New } \\
\text { Zealand, Singapore, Spain, UK, USA }\end{array}$ & $\begin{array}{l}\text { Brazil, India, Indonesia, Kazakhstan, Malaysia, Mongolia, Peru, } \\
\text { Russia, South Africa, South Korea, Thailand, Vietnam }\end{array}$ \\
\hline India & $\begin{array}{l}\text { Australia, Belgium, Canada, Denmark, Finland, France, } \\
\text { Germany, Ireland, Israel, Italy, Netherlands, New Zealand, } \\
\text { Norway, Singapore, Spain, Switzerland, UK, USA }\end{array}$ & $\begin{array}{l}\text { Argentina, Brazil, China, Czech Republic, Egypt, Indonesia, } \\
\text { Malaysia, Mauritius, Oman, Philippines, Poland, South Africa, } \\
\text { Sri Lanka, Thailand, United Arab }\end{array}$ \\
\hline Indonesia & Australia, Singapore & China, Malaysia \\
\hline Mexico & Canada, Spain, USA & Argentina, Brazil, Chile, Colombia, Costa Rica, El Salvador, Peru \\
\hline Russia & $\begin{array}{l}\text { Austria, Belgium, Canada, Finland, France, Germany, Israel, } \\
\text { Italy, Luxembourg, Netherlands, Spain, Switzerland, UK, USA }\end{array}$ & $\begin{array}{l}\text { Armenia, Belarus, Bulgaria, Cyprus, Czech Republic, Estonia, } \\
\text { Hungary, India, Kazakhstan, Latvia, Lithuania, Moldova, } \\
\text { Poland, Serbia, Turkey, Ukraine, Uzbekistan }\end{array}$ \\
\hline South Africa & Australia, Canada, France, Germany, Netherlands, UK, USA & $\begin{array}{l}\text { Brazil, Ghana, India, Kenya, Mozambique, Namibia, Nigeria, } \\
\text { Russia, South Korea, Tanzania, Uganda, Zambia, Zimbabwe }\end{array}$ \\
\hline Thailand & Australia, Japan, Singapore, USA & China, India, Indonesia, Malaysia, Philippines, Vietnam, \\
\hline Turkey & France, Germany, Netherlands, USA & Azerbaijan, Romania, Russia, \\
\hline Total country-year observations & 923 & 1053 \\
\hline
\end{tabular}

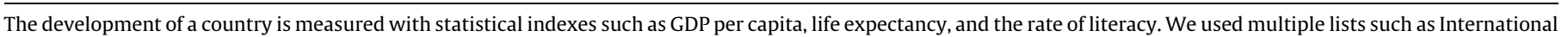

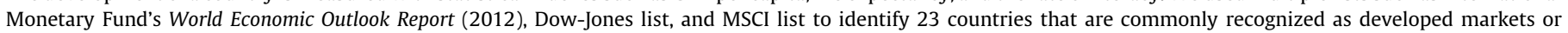

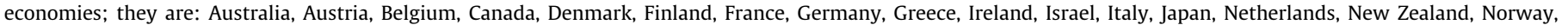

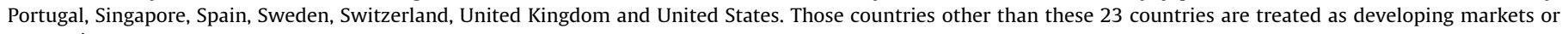
economies. 
Comparative empirical studies of OFDI by emerging market firms.

\begin{tabular}{|c|c|c|c|c|c|c|}
\hline Author(s) & Sample \& comparative nature & Theoretical perspective & Dependent variable & Independent variables & Control variables & Major results \\
\hline $\begin{array}{l}\text { Brienen, Burger, and } \\
\text { van Oort (2010) }\end{array}$ & $\begin{array}{l}\text { Chinese \& Indian greenfield } \\
\text { FDI in Europe in 1997-2008 } \\
\text { Chinese vs. Indian firms }\end{array}$ & $\begin{array}{l}\text { No theoretical framework; } \\
\text { theoretical rational based on } \\
\text { OLI paradigm }\end{array}$ & $\begin{array}{l}\text { Number of greenfield } \\
\text { investments }\end{array}$ & $\begin{array}{l}\text { GDP, transport infrastructure, } \\
\text { the presence of Chinese or } \\
\text { Indian community, labor and } \\
\text { capital costs }\end{array}$ & & $\begin{array}{l}\text { No differences in FDI } \\
\text { determinants; their FDI is } \\
\text { more horizontal than vertical } \\
\text { in character. Their greenfield } \\
\text { investments in Europe are } \\
\text { predominantly market } \\
\text { seeking, with partially for } \\
\text { asset-seeking motivations. }\end{array}$ \\
\hline Buckley et al. (2007) & $\begin{array}{l}\text { Chinese OFDI 1984-2001 } \\
\text { OECD vs. Non-OECD } \\
\text { countries }\end{array}$ & $\begin{array}{l}\text { OLI paradigm and } \\
\text { institutional theory }\end{array}$ & $\begin{array}{l}\text { Approved annual outflows of } \\
\text { Chinese FDI }\end{array}$ & $\begin{array}{l}\text { Market size, growth, natural } \\
\text { resource, political risk, } \\
\text { cultural proximity, and policy } \\
\text { liberation }\end{array}$ & $\begin{array}{l}\text { Exchange rate, inflation rate, } \\
\text { exports, imports, distance, } \\
\text { and open to FDI }\end{array}$ & $\begin{array}{l}\text { Chinese OFDI is associated } \\
\text { with high political risk, } \\
\text { market size, cultural } \\
\text { proximity, geographic } \\
\text { proximity and natural } \\
\text { resources. Export is } \\
\text { significant in both markets, } \\
\text { whereas import is significant } \\
\text { in non-OECD. }\end{array}$ \\
\hline Cheung and Qian (2009) & $\begin{array}{l}\text { China's OFDI in different } \\
\text { markets } \\
\text { Developed vs. Developing } \\
\text { countries }\end{array}$ & $\begin{array}{l}\text { No theoretical framework; } \\
\text { economic explanation }\end{array}$ & $\begin{array}{l}\text { China's OFDI stock in a } \\
\text { specific country }\end{array}$ & $\begin{array}{l}\text { GDP, GDP per capita, real } \\
\text { income growth rate of host } \\
\text { country, wage, raw resource, } \\
\text { risk }\end{array}$ & $\begin{array}{l}\text { Country distance, geography, } \\
\text { and culture resemblances }\end{array}$ & $\begin{array}{l}\text { China's investment in } \\
\text { developed and developing } \\
\text { countries are driven by } \\
\text { different sets of factors. }\end{array}$ \\
\hline $\begin{array}{l}\text { De Beule and Duanmu } \\
\text { (2012) }\end{array}$ & $\begin{array}{l}\text { Acquisitions by Chinese and } \\
\text { Indian firms from } 2000 \text { to } \\
2008 \\
\text { Chinese vs. Indian firms }\end{array}$ & $\begin{array}{l}\text { Lack of a clear theoretical } \\
\text { framework; based on } \\
\text { institutional variables }\end{array}$ & $\begin{array}{l}\text { The likelihood of entry into a } \\
\text { country }\end{array}$ & $\begin{array}{l}\text { Market size, openness, } \\
\text { institutional quality }\end{array}$ & $\begin{array}{l}\text { Geographical distance, deal } \\
\text { size, acquirer's size and } \\
\text { experience }\end{array}$ & $\begin{array}{l}\text { Better rule of law, regulatory } \\
\text { quality and control of } \\
\text { corruption are found to be } \\
\text { important for India's } \\
\text { acquisitions, not for China's } \\
\text { acquisitions. Political } \\
\text { stability is a negative } \\
\text { estimator for both countries. }\end{array}$ \\
\hline Duanmu (2012) & $\begin{array}{l}\text { Chinese OFDI: } 194 \text { location } \\
\text { choices in } 32 \text { countries from } \\
1999-2008 \\
\text { Developed vs. Developing } \\
\text { countries }\end{array}$ & $\begin{array}{l}\text { Lack of a clear theoretical } \\
\text { framework; based on } \\
\text { ownership and strategic } \\
\text { intent }\end{array}$ & $\begin{array}{l}\text { Country chosen (the choice of } \\
\text { the country }=1,0 \text { otherwise) }\end{array}$ & $\begin{array}{l}\text { Political risk; GDP, GDP per } \\
\text { capita, economic risk, } \\
\text { exchange rate. State-owned } \\
\text { vs. private; strategic intent }\end{array}$ & $\begin{array}{l}\text { Corporate tax, } \\
\text { unemployment rate, physical } \\
\text { distance }\end{array}$ & $\begin{array}{l}\text { GDP and GDP per capita } \\
\text { attain most significant } \\
\text { results. Strategic intent } \\
\text { affects location choice. Less } \\
\text { risky political environment } \\
\text { attracts more Chinese FDI, } \\
\text { while economic risk and } \\
\text { freedom not relevant. No } \\
\text { structurally substitution } \\
\text { between developed and } \\
\text { developing markets. }\end{array}$ \\
\hline $\begin{array}{l}\text { Hur, Parinduri \& } \\
\text { Riyanto (2011) }\end{array}$ & $\begin{array}{l}\text { M\&A outflows to different } \\
\text { markets } \\
\text { Developed vs. Developing } \\
\text { countries }\end{array}$ & $\begin{array}{l}\text { No theoretical framework; } \\
\text { rational based on quality of } \\
\text { institutions }\end{array}$ & $\begin{array}{l}\text { log of CBMA inflows to host } \\
\text { countries }\end{array}$ & $\begin{array}{l}\text { Quality of institutions and } \\
\text { composite index }\end{array}$ & $\begin{array}{l}\text { Economic size, trade, } \\
\text { technology, financial } \\
\text { development }\end{array}$ & $\begin{array}{l}\text { The disparity can be } \\
\text { attributed to the difference in } \\
\text { the quality of institutions } \\
\text { between developed and } \\
\text { developing countries. }\end{array}$ \\
\hline Hurst (2011) & $\begin{array}{l}\text { China's SOEs' FDI in OECD and } \\
\text { non-OECD countries 2003- } \\
2008 \\
\text { Developed vs. Developing } \\
\text { countries }\end{array}$ & $\begin{array}{l}\text { No theoretical framework; } \\
\text { investment motives based on } \\
\text { OLI paradigm }\end{array}$ & $\begin{array}{l}\text { Chinese FDI outflows to the } \\
\text { host country }\end{array}$ & $\begin{array}{l}\text { GDP, trade openness, } \\
\text { property freedom index, } \\
\text { natural resource, labor } \\
\text { freedom index }\end{array}$ & $\begin{array}{l}\text { Distance, cultural proximity, } \\
\text { government spending index }\end{array}$ & $\begin{array}{l}\text { The OLI paradigm provides an } \\
\text { excellent framework for the } \\
\text { determinants of Chinese SOE } \\
\text { investment in developed } \\
\text { countries, but needs } \\
\text { refinement for developing } \\
\text { countries. }\end{array}$ \\
\hline
\end{tabular}




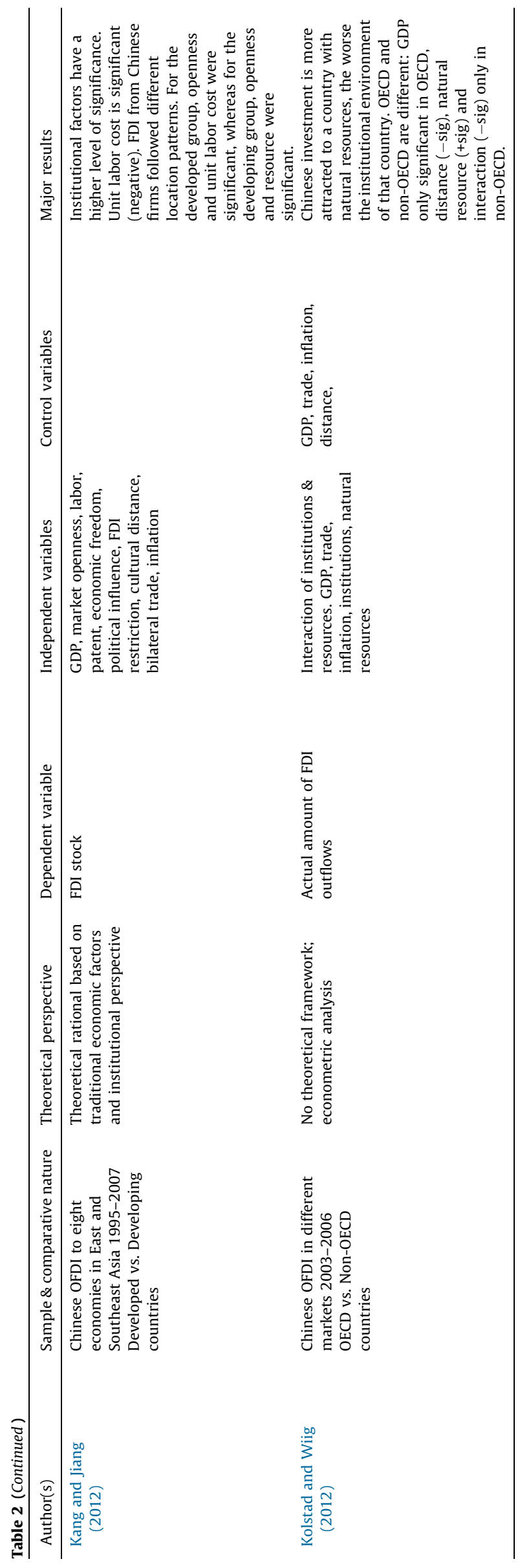

environments to stabilize resources exchanges, RDT could provide a pertinent theoretical framework in vigorously testing conflicting findings. In essence, RDT has been recognized as one of the dominant theoretical rationales for identifying the antecedents of acquisitions (Haleblian, Devers, McNamara, Carpenter, \& Davison, 2009; Hillman et al., 2009) and EMFs are increasingly using crossborder M\&As as a central option to obtain their needed vital resources so as to minimize environmental dependence (Peng, 2012; Rabbiosi, Stefano, \& Bertoni, 2012). Surprisingly, there is no study that adopts RDT in examining locational determinants of cross-border M\&As from emerging economies (Deng, 2013). We intend to fill this research by applying and extending the resource dependence perspective and analyze how EMF-host country interdependences influence the extent to which EMFs engage in international acquisitions in different markets.

\subsection{Resource dependence logics of MEAs}

The central argument of RDT is that firms depending on the environment can and do enact multiple strategies to combat their external constraints and procure critical resources (Pfeffer \& Salncik, 1978, 2003). Central to these actions is the concept of power, which is the control over vital resources (Oliver, 1990; Pfeffer, 1987). M\&As is one of the most important options that firms can enact to manage and minimize environmental uncertainty (Davis \& Cobb, 2010; Hillman et al., 2009). Unlike joint ventures (JVs) and other interorganizational options, M\&As represents a full constraint absorption and enables firms to acquire those firms that control their needed resources or needed by other firms, thereby enhancing their power relative to that of others (Casciaro \& Piskorski, 2005). By offering an externally focused perspective for understanding organizational environmental relations and resource enhancing effects (Pfeffer, 1987), RDT seems well positioned to enhance the market and resource discourse, thus becoming one of the most widely applied theoretical lenses to explain why firms engage in M\&As (Davis \& Cobb, 2010; Hillman et al., 2009). A notable shortcoming in the resource dependence literature is that little attention has been paid to cross-border M\&As by EMFs (Deng, 2013). As a consequence, whether the resource dependence perspective consistently explains the antecedents of M\&As under conditions of different country systems remains unknown.

Extending the resource dependence logic of M\&As (or simply the M\&A logic), we contend that facing external constraints a firm may invest overseas in order to increase its power by acquiring alternative sources of resources. For our research purpose, we define the M\&A logic as that a firm acquires and controls resources and thereby alleviates resource dependences on the external environment in which it is embedded (Davis \& Cobb, 2010; Dress \& Heugens, 2013). The M\&A logic suggests that EMF dependence on host countries is determined by the extent to which potential acquired firms control important resources or markets that are needed by EMFs. That is, the magnitude of resource dependency on host nations predicts the likelihood and formation of cross-border M\&As by EMFs, which in turn strengthen focal organizational autonomy and legitimacy (Pant \& Ramachandran, 2012; Sherer \& Lee, 2002).

Although RDT appears to be well established in terms of the general relationships between firms, their environments, and the actions firms take to reduce these dependences (Casciaro \& Piskorski, 2005; Sherer \& Lee, 2002), the M\&A logic has not been rigorously tested in global settings. In addition, most RDT studies on constraint absorption activities were mainly at the industry or firm level of analysis, virtually ignoring the country level (Casciaro \& Piskorski, 2005; Xia, Ma, Lu, \& Liu, 2013). Given that RDT is about firms' dependence on their environments, organizational activities 
should also be studied at the country level (Davis \& Cobb, 2010). By focusing on the country level of analysis, we intend to fill the gap, furthering our understanding of the M\&A logic in global settings. In so doing, our study takes a step further to complement those studies in the FDI literature which contend that EMFs acquire internationally is motivated for distinct reasons: (1) firms may invest overseas for the abundant natural resources or new markets in different host economies; (2) cross-border M\&As allow firms to acquire intangible or strategic resources which are either costly or unavailable in the home country but could be obtained overseas; and (3) firms may expand internationally due to a limited domestic market that may be insufficient to reduce their environmental uncertainty (e.g., Buckley et al., 2014; Deng, 2009; Luo \& Tung, 2007; Witt \& Lewin, 2007).

\subsection{Motivation to seek markets in the MEA logic}

From the resource dependence perspective, markets are not only channels of resources but also mechanisms to actually implement firms' strategies, representing the firms' ability to monitor and manipulate the flow of resources between countries (Davis \& Cobb, 2010). In an era of global interdependence, EMFs depend not only on other firms in the home country but also increasingly on other firms in foreign countries for raw materials, intermediate products, or downstream markets (Bhagata, Malhotrab, \& Zhu, 2011; Luo \& Wang, 2012). As the sources of some critical supplies or markets are not readily available domestically, the M\&A logic suggests that one way for EMFs to respond to such home constraint pressures is to expand into foreign markets by acquisition (Finkelstein, 1997; Xia et al., 2013). The rationale is as follows: A firm can expand into new geographic locations to reduce the constraints associated with dependence on present markets or actors, thereby altering the unfavorable power imbalance. To this end, M\&As may allow EMFs to gain more power and control over markets because acquisition can ensure continued flow of resources (Pfeffer \& Salancik, 2003). For example, acquiring and affiliations with prestigious local firms have been argued to help EMFs in undertaking marketing endeavors and overcome liabilities of market newness by conveying signals of legitimacy to consumers (Peng, 2012; Pollock, Chen, Jackson, \& Hambrick, 2010).

As local firms usually possess resources such as customers, channel controls, key supply sources, and relationships with regulators that cannot easily be replicated in the short term, EMFs can be motivated, to some extent, to stabilize and control the flow of such resources. On top of that, in an effort to exclude rivals, EMFs acquiring local firms who control limited but critical resources can gain more market power through the erection of entry barriers to block or restrict the entry of competitors (Gaffney, Kedia, \& Clampit, 2013; Shimizu, Hitt, Vaidyanath, \& Pisano, 2004). In addition, due to intense domestic competition and market dominance by some powerful players, EMFs are often unable to obtain sufficient market shares at home. Consequently, EMFs may escape by investing abroad to avoid the market constraints at home (Heeley, King, \& Covin, 2006; Witt \& Lewin, 2007). Such avoidance strategy is further rationalized when there are sufficient markets and distribution channels ready for acquisition overseas (Deng, 2009). This is in line with OLI paradigm, which contends that firms will decide in which country to undertake FDI according to the endowments of location-specific advantages of the host country (Dunning, 1995, 2009).

It is expected that large markets are capable of attracting M\&As due to economies of scale in production and distribution for goods and services sold in the host countries (Kyrkilis \& Pantelidis, 2003; Tolentino, 2010). On top of that, large markets are also associated with agglomeration economies that can reduce the costs for all producers in that market (Dunning, 2009). From a resource dependence lens, the market represents a pool of resources that EMFs can leverage to engage in M\&As, through asset, information, and legitimacy flows, thereby increasing the possibility of M\&A deals (Gaffney et al., 2013; Karney, 2012). As the financial wealth of the country is positively associated with the ability of EMFs to create firm-specific advantages, which have been identified as necessary to international acquisitions (Dunning, 1995; Kyrkilis \& Pantelidis, 2003; Sun, Peng, Ren, \& Yan, 2012), there are increasingly studies that have included financial market size as an important determinant of cross-border M\&As from emerging economies. Empirically, scholars (e.g., Di Giovanni, 2005; Nicholson \& Salaber, 2013) found that the size of host country's financial market, measured by the ratio of stock market capitalization to GDP, has a strong positive correlation to overseas M\&A activities. Similarly, Duanmu (2012) found that financial market size measured as host country's market capitalization is an important attraction for Chinese OFDI. Following the predictions of prior studies, we expect that the size of financial market in a host nation will positively affect the number of cross-border M\&As initiated by EMFs in both developed and developing countries. In essence, a large financial market contributes to some more demands in the input and output markets that created more purchasing potential for investors to identify opportunities and possess the resources to exploit those opportunities (Globerman \& Shapiro, 2005). Therefore:

H1. The size of host financial market is positively associated with the number of cross-border M\&As by emerging market firms in each host country.

\subsection{Motivation to seek resources in the MEA logic}

From a resource dependence lens, it is important to consider the resource aspect that drives M\&As, as firms rely on resource availability for future actions. To cope with environmental uncertainty, firms often resort to M\&As as part of their resource absorptive processes (Pfeffer \& Salancik, 1978, 2003). In particular, resources that firms get from different economies may affect their decisions toward acquisitions (Finkelstein, 1997). While some studies have incorporated the elements of resource acquisition in understanding driving forces behind cross-border M\&As, they have typically focused on the transaction role of acquisitions instead of control of resources, which may have different effects (Cheung \& Qian, 2009; Kang \& Jiang, 2012). In the following, we concentrate on the impact of resource (both natural resources and strategic assets) dependence in host countries on the subsequent M\&As by EMFs. Fundamentally, M\&As need to match the resources provided by the target firm with the need of the acquiring firm, and "resource-rich" countries should be the focus of international acquisitions by EMFs (Haleblian et al., 2009; Nicholson \& Salaber, 2013).

Acquiring and securing a continual supply of natural resources is one of the major motives for EMFs to engage in international acquisitions (Gaur, Kumar, \& Singh, 2014; Stucchi, 2012). Take China as example: the Chinese government has used OFDI to ensure the supply of domestically scarce factor inputs as the Chinese economy rapidly grows (Kang \& Jiang, 2012). Key natural resource sectors for Chinese firms to seek include minerals, petroleum, timber, fishery and agricultural products (Morck, Yeung, \& Zhao, 2008). This motive to seek natural resources has also been highlighted by a number of recent high-profile acquisitions by EMFs, including Brazil-based Cia Vale do Rio Doce's $\$ 18.2$ billion acquisition of Canada's Inco, Mexico-based Cemex's $\$ 15.1$ billion acquisition of Australia's Rinker Group, and India-based Tata Steel's \$12.5 billion acquisition of the U.K.-based Corus Group (Jullens, 2013; UNCTAD, 2014). Accordingly, we 
propose that EMFs will increase the number of cross-border M\&As in both developing and developing countries that have rich natural resources. Natural resource is another important factor characterizing host market that attracts cross-border M\&As by EMFs. Based on the M\&A logic, we propose the following hypothesis:

H2. The natural resources of a host country are positively associated with the number of cross-border M\&As by emerging market firms in each host country.

In addition to the natural resource, firms from emerging economies are motivated to obtain intangible resources and innovation-based knowledge through M\&As (Child and Rodriguez, 2005; Luo \& Tung, 2007). It has been argued that strategic assets such as superior marketing expertise, product differentiation, patent-protected technology, and managerial know-how constitute a major set of strategic motivations for EMFs to engage in international acquisitions particularly in advanced countries (Jullens, 2013; Rabbiosi et al., 2013). Empirical studies also verify that many of EMFs investing in advanced countries have gained access to established brand names, novel product technology, and extensive networks of distributors, typically via aggressive acquisitions of developed market firms in host countries (Nicholson \& Salaber, 2013; Su, 2013). An example here is the Lenovo's acquisition of IBM's PC group in 2005. This acquisition makes Lenovo immediately become the third largest PC supplier in the world. In the same vein, EMFs are looking at developed countries to gain access to high quality research and development (R\&D) institutions and workforces not found at home (Abrami, Kirby, \& McFarlan, 2014; Chen, Li, \& Shapiro, 2012). For instance, many Indian software firms with ownership advantages had moved abroad to acquire innovation-based skills as well as proprietary technology that were not available domestically (Gaur et al., 2014).

When entering foreign markets to seek strategic assets, EMFs are more likely to internalize the business through acquisitions rather than other alternative options such as alliance and JVs. This is because M\&As is more likely to decrease the opportunity costs for the EMFs to absorb critical resources, such as advanced technologies or managerial skills (Chen et al., 2012; Williamson, 1991). On top of that, M\&As may help the EMFs to control some important sources of resources, thus not only streamlining operations but also enhancing their bargaining power relative to local firms, thus mitigating dependence uncertainties (Gaffney et al., 2013; Haleblian et al., 2009). Given that cross-border M\&As is increasingly becoming an important strategic response for EMFs to acquire advanced technology and know-how for constraint absorption in host countries, we have the following hypothesis:

H3. The strategic asset of a host country is positively associated with the number of cross-border M\&As by emerging market firms in each host country.

\subsection{Government effectiveness as a boundary condition}

So far, we have looked at the independent effects of resource dependencies on the intensity of cross-border M\&As by EMFs without worrying about the moderating effects. We further argue that the M\&A logic is bounded by the level of host government effectiveness, an important institutional variable which has been ignored in RDT literature. Government effectiveness is an integral part of institutional systems which represents a host nation's institutional governance and reflects perceptions of the quality of public services and the quality of policy formulation and implementation (Kaufmann, Kraay, \& Mastruzzi, 2010). The ability of host governments to design and implement effective and sound economic and regulative policies is an essential prerequisite for foreign investors to engage in international acquisition activities (Lin, Peng, Yang, \& Sun, 2009). Without such efficient and effective policies, the development of economic opportunities will be curtailed, making them less attractive to foreign investors (Kamaly, 2007; Peng, Wang, \& Jiang, 2008). The literature on multinationalshost government interactions suggests that host governments often have substantial bargaining power over foreign investors (Hillman, Kein, \& Schuler, 2004). As Boddewyn and Brewer (1994) observed that once a foreign firm invests in a host country, its bargaining power over local government declines.

For our research purpose, we focus on host government effectiveness as temporal conditions on RDT applications so as to offer further insights into how the M\&A logic is more predictive of EMFs in their cross-border M\&A endeavors. Resource dependence scholars have focused on how to enhance the power of acquiring firms through M\&As so as to reduce competition (Santos \& Eisenhardt, 2005). By absorbing an important competitor, however, EMFs inevitably are closely monitored by the host government (Matsusaka, 1996; Peng et al., 2008). In essence, since RDT's managerial prescriptions frequently stand in tense relationship to prevailing anti-trust rules, the theory's explanatory power is impacted by competition laws which are more likely to be enforced in the host countries where their government effectiveness is high. In explaining why host government effectiveness may negatively moderate the M\&A logic that applies to cross-border M\&As by EMFs, we focus on three dominant mechanisms.

First, high government effectiveness in a host nation arguably leads to strong institutions in the area of anti-trust laws (Matsusaka, 1996). While RDT regards M\&As as important instruments for mitigating resource dependencies, antitrust authorities (legislation) have long looked upon them with suspicion (Peng et al., 2008). In particular, host governments see M\&As as having the potential to reduce direct competition by enhancing the market power of the acquirers and by lessening the competitive pressure like quality-based differentiation (Santos \& Eisenhardt, 2005). The possible consequences of such anticompetitive behaviors are that consumers are presented with deadweight losses due to monopolistic pricing and with slowing product innovation (Shapiro, 2010). National governments like that of the U.S. and supranational institutions like the European Union have therefore long been keen to prevent corporate market dominance by regulating the formation of M\&As through antitrust legislation (Finkelstein, 1997). For example, in highly regulated industries, there tend to have a lower proportion of M\&As (Hillman et al., 2004). Based on the meta-analysis of 157 resource dependence studies (1999-2009), Dress et al. (2013: 1690) conclude "the tenability of RDT is dependent on the stringency of the anticompetitive regime in a certain context or time period; the more stringent the regime, the weaker the potential of RDT to predict organizational behavior."

Second, as antitrust law is predominantly focused on M\&As, stricter antirust legislation might create substitution effects with other less regulated interorganizational options (Bower, 2001; Haleblian et al., 2009). This is because when firms are abandoning M\&As as their primary vehicle for collusion and anticompetitive action, they seem to be turning toward alternative options like alliance and JV relationships as a means for tacit coordination (Finkelstein, 1997). Empirical findings verify that the passing of stricter anti-merger legislation causes organizations to seek refuge in other, less regulated types of options (Dress \& Heugens, 2013). In essence, while all corporate arrangements can in principle be used as vehicle for collusion, antitrust legislation is primarily intended to prevent the formation of positions of market dominance through M\&As.

Third, with high government effectiveness, a focal firm may find it more efficient to leverage its strategic position through alliance 
or JVs while less necessary to pursue acquisitions, which may entail much higher risks and uncertainty due to more irreversible equity commitments (Das \& Teng, 2001). This is because in more developed institutional setting, the established business environment provides sufficient legal protection for market behaviors and reduces potential opportunistic behaviors (Lin et al., 2009). Moreover, the reliability of market monitoring mechanisms helps ensure the benefit from such alliance and JV relations for focal firms. Conversely, in an undeveloped institutional setting, where the business environment is fragile and legal protection is insufficient, there is potentially a high threat of opportunism by alliance partners that significantly increase cooperation cost to an EMF (Das \& Teng, 2001). According to a market failure logic that assumes acquisitions to be the result of costly or difficult market exchanges (Williamson, 1991), focal firms facing underdeveloped institutions may be more inclined to acquire others for better control of resources. These arguments lead to the following interaction hypothesis:

H4. The relationship between the size of host financial market and the number of cross-border M\&As by emerging market firms will be negatively moderated by the government effectiveness of host market. Specifically, a higher (lower) government effectiveness will lead to fewer (more) cross-border M\&As in each host country.

The above three dominant mechanisms are equally applied to those EMFs who are motivated for resource acquisition in their overseas acquisitions. Compared with market power established via cross-border M\&As, host governments tend to be more sensitive to EMFs in terms of strategic-asset seeking endeavors. This is because equipped with acquired innovation-based knowledge, EMFs are more likely to become meaningful challengers to home-based multinationals (Jullens, 2013; Sun et al., 2012). With high government effectiveness, host nations are most likely to prevent cross-border deals by EMFs not simply based on competitive laws but also under national interest concerns (Bremmer, 2014; Deng, 2013). Accordingly, as strategic choices cross-border M\&As are not only driven by firms' resource needs, but also are a reflection of the institutional constraints faced by firms (Peng et al., 2008). On top of that, stricter anti-merger legislation may hurt the attractiveness of subsequent M\&As because of the frequent demands by antitrust authorities to divest some of the valuable assets stemming from the M\&As (Santos \& Eisenhardt, 2005). When facing EMF-host country interdependence pressures, EMFs may have to adapt themselves based on the level of host government effectiveness, even though acquisition may help them reduce the constraints exerted by powerful players in different contexts. As a consequence, the following two moderating hypotheses are proposed:

H5a. The relationship between the natural resources of a host country and the number of cross-border M\&As by emerging market firms will be negatively moderated by the government effectiveness of host market. Specifically, a higher (lower) government effectiveness will lead to fewer (more) cross-border M\&As in each host country.

H5b. The relationship between the strategic asset of a host country and the number of cross-border M\&As by emerging market firms will be negatively moderated by the government effectiveness of host market. Specifically, a higher (lower) government effectiveness will lead to fewer (more) cross-border M\&As in each host country.

\section{Data and methods}

We use three different data sources to create the dataset for this study. The first is "SDC Platinum Database" produced by Thomson
Financial Corporation, which provides data on aggregate crossborder M\&A activities by EMFs. The second is the Worldwide Governance Indicators dataset created by Kaufmann et al. (2010), which can be accessed by the World Bank Database (2013). This research dataset constructs aggregate indicators of six broad dimensions of governance for 215 countries and territories from 1996 to 2012. The third data source is the World Development Indicators Database, which provides country-level variables such as patents, and financial market development. This database is the primary World Bank collection of development indicators, compiled from officially-recognized sources. Currently, it includes over 800 indicators covering more than 210 developing and developed countries. Our study included all completed overseas M\&As initiated by firms from nine emerging countries (Brazil, China, India, Indonesia, Mexico, Russia, South Africa, Thailand, and Turkey) in developed and developing markets from 2000 to 2012. We excluded a small group of target countries that did not show sufficient M\&A activities within our observation window (e.g., fewer than five deals over thirteen years), thus leading to approximately $97 \%$ of M\&A deals by these nine emerging countries in this database. The final sample size in developed markets is 923 country-year observations over the period of 2000-2012 and in the developing countries there are 1053 country-year observations (see Table 1).

\subsection{Variable measurement}

In our study, the dependent variable is the number of crossborder M\&As in each host market (\#deals). It was measured by the total number of complete M\&A deals made by firms of the nine EMFs in each host country each year. There are three reasons to adopt the number of cross-border M\&As rather than volume (aggregate amount) of M\&As to each host market as the dependent variable. First, prior research on cross-border M\&As tended to use the aggregate amount of OFDI flows to capture the involvement of a country's foreign investment or takeover. This approach faces the limitation in that extreme size (too big or too small) of M\&As manipulates influences or significantly changes this measure (Dikova, Rao, \& van Witteloostuijn, 2010). We choose to use the number of M\&A deals to measure the level of acquisition activity so that each deal can be equally and fairly treated. Second, the transaction size for each M\&A deal in SDC database has a large missing value. Using aggregate value of cross-border M\&As as the dependent variable will lead to a small sample size with the possibility of bias and non-representativeness (Zhang, Zhou, \& Ebbers, 2011). Third, in recent years, more and more scholars prove that use of number of investment projects as the dependent variable is an effective alternative to examining cross-border M\&As by EMFs (e.g., Lin et al., 2009; Zhang et al., 2011). This measurement can address, at least partially, some criticisms about use of aggregate amount of M\&As as an overarching measure to capture overseas M\&A activities.

For the explanatory variables that capture the market-seeking motive, we followed Globerman and Shapiro (2005) to use the ratio of stock market capitalization to GDP (Mktcap) to represent the size of financial market of each host market. Given that our research focus is on cross-border M\&As, the financial market size is a superior measure of the underlying construct. This is because the ratio of stock market capitalization to GDP better represents the number of potential firms available to be acquired in both developed and developing nations. For the resource-seeking variable, we took natural resource (Natural resources) measured as ratio of ore and metal exports to merchandize exports in the host country. Following Buckley et al. (2007), we then took Patents, the total number of patent registrations (both resident and non-resident) in a host country, as a proxy of strategic asset-seeking variable. 
As to the moderating variable, we adopted the measure of government effectiveness (Gov. effectiveness), one of the six worldwide governance indicators developed by Kaufmann et al. (2010), to represent the effectiveness of host government. Derived from the World Bank Database (2013), Gov. effectiveness is a timevarying and country-level governance indicator measured as a percentile rank among all countries ranging from 0 (lowest) to 100 (highest) to reflect perceptions of the quality of public services, civil services and policy as well as the degree of governmental independence from political pressures. To test moderating effects, we followed Connelly, Tihanyi, Certo, and Hitt (2010) and PennerHahn and Shaver (2005) to split the sample into two subsamples by the mean of Gov. effectiveness (high vs. low).

In terms of control variables, we used Home GDP growth, Home Mktcap and Foreign reserves from the World Bank database to capture the effect of home market on foreign investment activities. Home GDP growth was measured by the annual growth rate of GDP in each home country of acquiring EMFs. Similar to Mktcap, Home Mktcap was measured by the ratio of stock market capitalization to GDP of each acquiring firms' home country. Foreign reserves refers to the total value in current US dollars of foreign exchange reserves of each home country of acquiring firms, measured by the holdings of monetary gold, special drawing rights, and reserves of IMF members held by the IMF. It is argued that companies from large home markets with sound developed financial environment are more inclined to invest abroad because such large domestic economy brings them country-based advantages for global competition (Luo \& Wang, 2012; Tolentino, 2010). Moreover, we used Cultural distance to control the influence of cultural distance; it was measured as the extent of the difference between the national culture of acquiring firms and those of target firms in terms of Hofstede's four cultural dimensions. Similar to prior research (e.g., Brouthers, Brouthers, \& Werner, 2008), we follow Kogut and Singh's (1988) method to combine the four dimensions of cultural distance into one composite variable. It is expected that cultural distance will increase the level of uncertainty in the process of cross-border M\&As so that the level of M\&As will decrease when the cultural distance between home and host countries is high (Kang \& Jiang, 2012). Finally, we used the number of overseas M\&As in host markets in the prior year (\#Deals $t-1$ ) to control the influence that prior M\&As would bring to current investment activities.

\subsection{Statistical method and analysis}

The dependent variable of our investigation was a count variable (the number of cross-border M\&As in each host country), which ranges from zero to a certain positive number. As it is nonnegative, it is inappropriate to adopt standard multiple regression models. A count data can be modeled as a Poisson or negative binomial regression model. Although Poisson regression ensures that zero values of the dependent variable are incorporated into a model, it cannot handle the variance rate, termed overdispersion because it assumes that the event (the number of M\&As) occurs at some rate over a period of time. We thus consider a negative binomial regression model as a better choice to analyze data since it generalizes the Poisson model by allowing the rate of the underlying process to vary across observations according to a gamma distribution (Greene, 2003; Hilbe, 2007). On top of that, standard negative binomial models might not be able to handle the presence of excess zero counts in the number of cross-border M\&A data. Therefore, we followed Greene's (2003) recommendation to apply the Vuong test (Vuong, 1989) to determine whether a zeroinflated negative binomial regression is a better technique than the standard negative binomial model. Because the Vuong $Z$-scores in our study are not significant $(p<.05)$, we decided to adopt negative binomial models to analyze data.

As our longitudinal panel data contain repeated observations across years, our analyses also need to address the issue related to lack of independence and unobserved heterogeneity (Allison, 1995; Greene, 2003). Both biases may lead to underestimation of the true standard error, which inflates the significance tests that are associated with the parameter estimates. To address these issues, we employed a random-effect negative binominal model and reported the robust standard errors that are derived from the robust variance estimator (Hilbe, 2007). Using the robust standard errors allows us to relax the assumption that observations across years are independent, thus helping us obtain better estimates of parameters. Finally, we lagged all independent variables by one year so as to avoid possible endogeneity with the dependent variable in the model.

\section{Results}

Tables 3 and 4 present the descriptive statistics and correlation matrix for all variables used in this study in the setting of developed and developing markets, respectively. Although variables in the correlation matrix are not highly correlated, we still ran the variance inflation factor test. As the test results are less than 10 , no serious collinearity is found (Kutner, Nachtsheim, \& Neter, 2004). We then keep all these variables in the regression models.

Table 5 reports the results of negative binomial regression analysis in developed markets. Model 1 is the baseline model that includes only the control variables and the moderating variable (Gov. effectiveness). Models 2 to 4 test the main effects of the four motives on cross-border M\&As, respectively. Model 5 adds all the independent variables to serve as a baseline model for Model 6, which shows the interaction effects.

Table 3

Descriptive statistics and correlations for the No. of CBMAs by EMNCs in Developed Markets, 2000-2012

\begin{tabular}{|c|c|c|c|c|c|c|c|c|c|c|c|}
\hline Variable & Mean & s.d. & 1 & 2 & 3 & 4 & 5 & 6 & 7 & 11 & 8 \\
\hline 1. \# M\&As & 2.52 & 4.76 & & & & & & & & & \\
\hline 2. Mktcap & 100.58 & 53.66 & $.17^{* * *}$ & & & & & & & & \\
\hline 3. Natural resource & 4.35 & 5.64 & $.14^{* * *}$ & $.08^{*}$ & & & & & & & \\
\hline 4. Patents (log) & 3.81 & 0.85 & $30^{* * * *}$ & $-.07^{*}$ & $-.13^{* * *}$ & & & & & & \\
\hline 5. Gov. effectiveness & 91.92 & 6.70 & $-.14^{* * *}$ & $.43^{* * *}$ & $.12^{* *}$ & $.32^{* * *}$ & & & & & \\
\hline 6. Home GDP growth & 5.86 & 3.71 & $.17^{* * *}$ & .06 & .02 & -.05 & .02 & & & & \\
\hline 7. Home Mktcap & 69.76 & 57.17 & $.16^{* * *}$ & $.07^{*}$ & $.14^{* * *}$ & $.08^{*}$ & .02 & .01 & & & \\
\hline 8. Foreign reserve & 11.07 & .58 & $.19^{* * *}$ & $-.14^{* * *}$ & .04 & -.02 & $-.13^{* * *}$ & $.41^{* * * *}$ & $-.08^{* *}$ & & \\
\hline 9. Cultural distance & 2.11 & 1.11 & -.02 & -.03 & $.10^{* *}$ & $.12^{* * *}$ & $.12^{* *}$ & $.18^{* * *}$ & $-.22^{* * *}$ & $.30^{* * *}$ & \\
\hline
\end{tabular}

a $N=923$.

${ }^{*} p<.05$.

*** $p<.01$

$p<.001$ 
Table 4

Descriptive statistics and correlations for the No. of CBMAs by EMNCs in Developing Markets, 2000-2012.

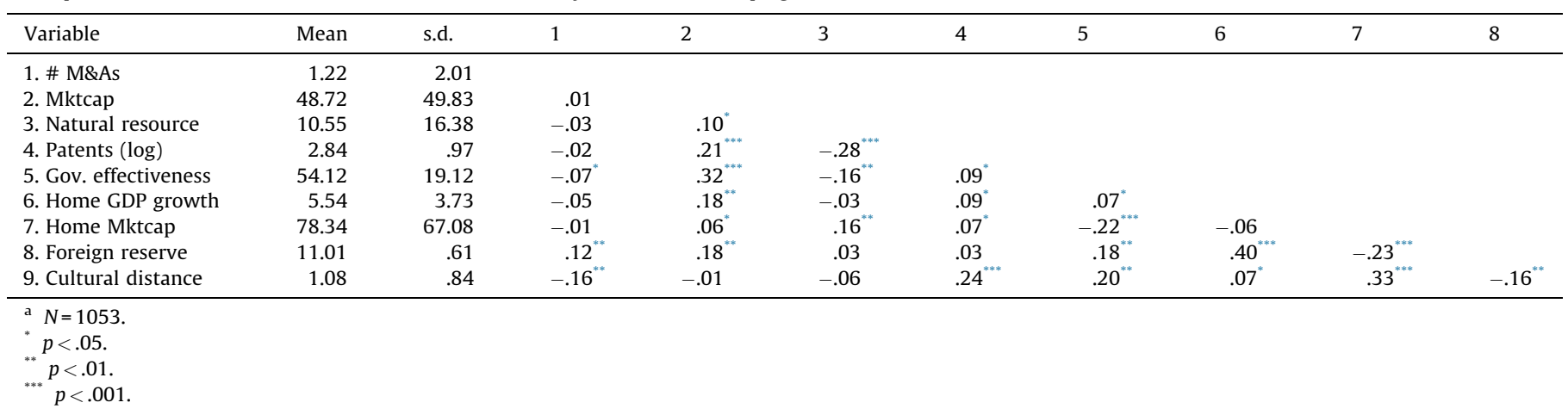

Table 5

Negative binomial regression analysis of the No. of CBMAs in developed markets, 2000-2012.

\begin{tabular}{|c|c|c|c|c|c|c|c|}
\hline \multirow[t]{2}{*}{ Independent variables } & \multirow[t]{2}{*}{ Model 1} & \multirow{2}{*}{$\begin{array}{l}\text { Model } 2 \\
\text { H1 }\end{array}$} & \multirow{2}{*}{$\begin{array}{l}\text { Model } 3 \\
\mathrm{H} 2\end{array}$} & \multirow{2}{*}{$\begin{array}{l}\text { Model } 4 \\
\text { H3 }\end{array}$} & \multirow{2}{*}{$\begin{array}{l}\text { Model } 5 \\
\text { All main effects }\end{array}$} & \multicolumn{2}{|l|}{ Model $6^{\mathrm{a}}$} \\
\hline & & & & & & High Gov. effectiveness & Low Gov. effectiveness \\
\hline Intercept & $\begin{array}{l}-5.189 \\
(.961)\end{array}$ & $\begin{array}{l}-5.977^{* * *} \\
(1.152)\end{array}$ & $\begin{array}{l}-4.850^{* * *} \\
(.999)\end{array}$ & $\begin{array}{l}-7.362^{* * *} \\
(1.044)\end{array}$ & $\begin{array}{l}-10.161^{* * *} \\
(1.109)\end{array}$ & $\begin{array}{l}-4.318^{* *} \\
(1.490)\end{array}$ & $\begin{array}{l}-14.052^{* * *} \\
(1.769)\end{array}$ \\
\hline Home GDP growth & $\begin{array}{l}.013 \\
(.012)\end{array}$ & $\begin{array}{l}.001 \\
(.011)\end{array}$ & $\begin{array}{l}.016 \\
(.013)\end{array}$ & $\begin{array}{l}.016 \\
(.012)\end{array}$ & $\begin{array}{l}.012 \\
(.012)\end{array}$ & $\begin{array}{l}.032 \\
(.017) \\
.068\end{array}$ & $\begin{array}{l}.002 \\
(.015) \\
.007\end{array}$ \\
\hline Home Mktcap & $\begin{array}{l}.003^{* * *} \\
(.001)\end{array}$ & $\begin{array}{l}.002^{* *} \\
(.000)\end{array}$ & $\begin{array}{l}.002^{* *} \\
(.000)\end{array}$ & $\begin{array}{l}.003^{* *} \\
(.001)\end{array}$ & $\begin{array}{l}.002^{*} \\
(.001)\end{array}$ & $\begin{array}{l}.003^{* *} \\
(.001) \\
.006\end{array}$ & $\begin{array}{l}.001 \\
(.000) \\
.003\end{array}$ \\
\hline Foreign reserve & $\begin{array}{l}.453^{* * * *} \\
(.088)\end{array}$ & $\begin{array}{l}.549^{* * *} \\
(.090)\end{array}$ & $\begin{array}{l}.426^{* * *} \\
(.089)\end{array}$ & $\begin{array}{l}.527^{* * *} \\
(.090)\end{array}$ & $\begin{array}{l}.714^{* * *} \\
(.094)\end{array}$ & $\begin{array}{l}.494^{* * *} \\
(.121) \\
.928\end{array}$ & $\begin{array}{l}.941^{* * *} \\
(.152) \\
2.015\end{array}$ \\
\hline Cultural distance & $\begin{array}{l}-.026^{* *} \\
(.001)\end{array}$ & $\begin{array}{l}-.009 \\
(.040)\end{array}$ & $\begin{array}{l}-.046 \\
(.041)\end{array}$ & $\begin{array}{l}-.061 \\
(.042)\end{array}$ & $\begin{array}{l}-.031 \\
(.046)\end{array}$ & $\begin{array}{l}-.208 \\
(.054) \\
-.416\end{array}$ & $\begin{array}{l}-.048 \\
(.068) \\
-.101\end{array}$ \\
\hline \#Deals t-1 & $\begin{array}{l}.059^{* * *} \\
(.003)\end{array}$ & $\begin{array}{l}.058^{* * * *} \\
(.002)\end{array}$ & $\begin{array}{l}.058^{* * * *} \\
(.003)\end{array}$ & $\begin{array}{l}.058^{* * *} \\
(.003)\end{array}$ & $\begin{array}{l}.037^{* * *} \\
(.003)\end{array}$ & $\begin{array}{l}.070^{* * * *} \\
(.009) \\
.146\end{array}$ & $\begin{array}{l}.020^{* * *} \\
(.004) \\
.044\end{array}$ \\
\hline Gov. effectiveness & $\begin{array}{l}-.005^{* *} \\
(.001)\end{array}$ & $\begin{array}{l}-.012^{*} \\
(.006)\end{array}$ & $\begin{array}{l}-.006^{* *} \\
(.001)\end{array}$ & $\begin{array}{l}-.004^{* *} \\
(.001)\end{array}$ & $\begin{array}{l}-.006^{* *} \\
(.002)\end{array}$ & $\begin{array}{l}-.029^{* * * *} \\
(.007) \\
-.063\end{array}$ & $\begin{array}{l}-.012 \\
(.010) \\
.029\end{array}$ \\
\hline Mktcap & & $\begin{array}{l}.005^{* * *} \\
(.001)\end{array}$ & & & $\begin{array}{l}.006^{* * *} \\
(.001)\end{array}$ & $\begin{array}{l}.004^{* * *} \\
(.001) \\
.008\end{array}$ & $\begin{array}{l}.010^{* * *} \\
(.002) \\
.026\end{array}$ \\
\hline Natural resources & & & $\begin{array}{l}.020^{* * *} \\
(.004)\end{array}$ & & $\begin{array}{l}.035^{* * *} \\
(.005)\end{array}$ & $\begin{array}{l}.015^{*} \\
(.006) \\
.035\end{array}$ & $\begin{array}{l}.041^{* * *} \\
(.012) \\
.092\end{array}$ \\
\hline Patents & & & & $\begin{array}{l}.347^{* * *} \\
(.049)\end{array}$ & $\begin{array}{l}.411^{* * *} \\
(.050)\end{array}$ & $\begin{array}{l}.232^{*} \\
(.071) \\
.482\end{array}$ & $\begin{array}{l}.716^{* * * *} \\
(.085) \\
1.513\end{array}$ \\
\hline Log likelihood & -1690.51 & -1672.60 & -1682.87 & -1661.09 & -1605.78 & -898.40 & -672.82 \\
\hline Wald Chi-square & $733.76^{* * *}$ & $768.56^{* * *}$ & $746.11^{* * *}$ & $770.08^{* * *}$ & $901.94^{* * *}$ & $322.69^{* * *}$ & $471.00^{* * *}$ \\
\hline Sample size & 923 & 923 & 923 & 923 & 923 & 545 & 378 \\
\hline
\end{tabular}

a Figures in cells of Model 6 are estimated coefficient/standard deviation/average marginal effect.

${ }^{*} p<.05$.

${ }_{* * *}^{* *} p<.01$.

*** $p<.001$.

${ }^{+} p<.10$.

Hypotheses 1, 2, and 3 state that the effects of financial market size (Mktcap), resource (Natural resource) and strategic asset (Patents) are positively related to the number of cross-border M\&As in each host market. In Table 5, the coefficients of Mktcap are positive and significant $(p<.001)$ in Models 2 and 5. In addition, the coefficients of Natural resource are positive and significant $(p<.001)$ in Models 3 and 5 ; the coefficients of Patents are positive and significant $(p<.001$ and $p<.05)$ in Models 4 and 5. Therefore, Hypotheses 1, 2, and 3 are supported in the setting of developed markets. As for the magnitude of these effects, the coefficient of Mktcap in Model 2 is 0.005 , which means that for each one-unit increase in the size of financial market of host market, the expected number of M\&As in this market would increase by a factor of $\exp (0.005)=1.005$, while holding the other variables in the model constant. Likewise, in terms of the magnitude of the effect of Patents (with coefficient of 0.347 in Model 4), the number of M\&As in host markets is expected to increase in 1.415 unit when the strategic asset (e.g., number of patents) of host country increases in one unit. On top of that, this magnitude of the effect of Patents is higher than that of Mktcap and that of Natural resource $(\exp (0.20)=1.02$ in Model 3). To conclude, the bigger the market size of developed countries and the richer natural resources and strategic assets of these countries, the higher the number of crossborder M\&As by EMFs in these developed countries. 
Hypotheses 4, 5a, and 5b suggest that the level of host government effectiveness reduces the effects of financial market size (Mktcap), resource (Natural resource) and strategic asset (Patents) on the number of cross-border M\&As in host markets. As mentioned earlier, we split the sample into two subsamples by the mean of government effectiveness (high vs. low) to test these moderating effects. We examined the marginal effects of the independent variables on the dependent variable for each subsample. As shown in Model 6 of Table 5, under low government effectiveness, the coefficients of Mktcap, Natural resource and Patents are all positive and significant $(p<.001)$. The average marginal effects of these variables are higher than those in the subsample of high government effectiveness (e.g., $0.056>0.011$ for Mktcap and $1.513>0.483$ for Patents), thus Hypotheses 4, 5a, and $5 \mathrm{~b}$ are supported. Therefore, we can conclude that when EMFs undertake cross-border M\&As in developed countries, the weaker host government effectiveness, the stronger the relationships between the number of cross-border M\&As and the size of host market and the richness of natural resources and strategic assets of these countries.

Table 6 reports the results of the negative binomial regression analysis in developing markets. Similar to Table 5, Model 1 is the baseline model and Model 5 adds all the independent variables to serve as a baseline model for Model 6, which shows the interaction effects.

For the main effect of market-seeking motive, the coefficients of Mktcap are positive and significant $(p<.05)$ in Models 2 and 5. In addition, the coefficients of Natural resource are positive and significant $(p<.001$ and $p<.05)$ in Models 3 and 5 , whereas the coefficients of Patents are positive but not significant in Models 4 and 5. Therefore, Hypotheses 1 and 2 are supported in the setting of developing markets, whereas Hypotheses 3 is not. As for the magnitude of these main effects, the coefficient of Natural resource in Model 3 is 0.035 , which means that for each one-unit increase in Natural resource of host market, the expected number of M\&As in this market would increase by 1.036 unit. In short, the bigger the size of financial market and the richer natural resource of developing countries, the higher the number of cross-border M\&As by EMFs in these countries.

In terms of the moderating effects, Model 6 of Table 6 shows that under low government effectiveness, the coefficients of Mktcap and Patents are all positive and significant $(p<.05$ and $p<.01)$. The average marginal effects of these variables are also higher than those in the subsample of high government effectiveness (e.g., $0.014>0.005$ for Mktcap and $0.306>0.055$ for Patents). Therefore, Hypotheses 4 and $5 \mathrm{~b}$ are supported. That is, a weaker host government effectiveness positively influences the relationship between the number of cross-border M\&As by EMFs in developing countries and the size of host market and the richness of strategic assets of these countries. However, Hypothesis $5 \mathrm{a}$ is not supported because the coefficient of Natural resource is positive and significant $(p<.05)$ in the subsample of high government effectiveness. Contradictory to our prediction, government effectiveness in host developing countries positively rather than negatively moderates the relationship between the number of cross-border M\&As and the level of natural resources of host markets. This result could be explained as follows: When acquiring natural resources in developing markets, EMFs would consider high government effectiveness as facilitator

Table 6

Negative binomial regression analysis of the No. of CBMAs in developing markets, 2000-2012.

\begin{tabular}{|c|c|c|c|c|c|c|c|}
\hline \multirow[t]{2}{*}{ Independent variables } & \multirow{2}{*}{$\begin{array}{l}\text { Model } 1 \\
\text { Control only }\end{array}$} & \multirow{2}{*}{$\begin{array}{l}\text { Model2 } \\
\text { H1 }\end{array}$} & \multirow{2}{*}{$\begin{array}{l}\text { Model } 3 \\
\text { H2 }\end{array}$} & \multirow{2}{*}{$\begin{array}{l}\text { Model } 4 \\
\text { H3 }\end{array}$} & \multirow{2}{*}{$\begin{array}{l}\text { Model } 5 \\
\text { All main effects }\end{array}$} & \multicolumn{2}{|l|}{ Model $6^{a}$} \\
\hline & & & & & & High Gov. effectiveness & Low Gov. effectiveness \\
\hline Intercept & $\begin{array}{l}-3.393^{*} \\
(1.406)\end{array}$ & $\begin{array}{l}-3.001^{*} \\
(1.425)\end{array}$ & $\begin{array}{l}-3.478^{*} \\
(1.421)\end{array}$ & $\begin{array}{l}-3.133^{*} \\
(1.492)\end{array}$ & $\begin{array}{l}-2.941 \\
(1.509)\end{array}$ & $\begin{array}{l}-1.159 \\
(2.003)\end{array}$ & $\begin{array}{l}-4.482+ \\
(2.463)\end{array}$ \\
\hline Home GDPgrowth & $\begin{array}{l}.002 \\
(.015)\end{array}$ & $\begin{array}{l}.003 \\
(.015)\end{array}$ & $\begin{array}{l}.003 \\
(.015)\end{array}$ & $\begin{array}{l}.005 \\
(.015)\end{array}$ & $\begin{array}{l}.002 \\
(.015)\end{array}$ & $\begin{array}{l}.003 \\
(.019) \\
.005\end{array}$ & $\begin{array}{l}.014 \\
(.024) \\
.025\end{array}$ \\
\hline Home Mktcap & $\begin{array}{l}.006^{* * * *} \\
(.001)\end{array}$ & $\begin{array}{l}.006^{* * *} \\
(.002)\end{array}$ & $\begin{array}{l}.006^{* * *} \\
(.002)\end{array}$ & $\begin{array}{l}.006^{* * * *} \\
(.001)\end{array}$ & $\begin{array}{l}.006^{* * *} \\
(.001)\end{array}$ & $\begin{array}{l}.006^{* * *} \\
(.002) \\
.007\end{array}$ & $\begin{array}{l}.006^{*} \\
(.002) \\
.010\end{array}$ \\
\hline Foreign reserve & $\begin{array}{l}.309^{*} \\
(.127)\end{array}$ & $\begin{array}{l}.287^{*} \\
(.128)\end{array}$ & $\begin{array}{l}.322^{*} \\
(.129)\end{array}$ & $\begin{array}{l}.281^{*} \\
(.135)\end{array}$ & $\begin{array}{l}.297^{*} \\
(.136)\end{array}$ & $\begin{array}{l}.154 \\
(.177) \\
.162\end{array}$ & $\begin{array}{l}.328^{* *} \\
(.123) \\
.481\end{array}$ \\
\hline Cultural distance & $\begin{array}{l}-.198^{* *} \\
(.073)\end{array}$ & $\begin{array}{l}-.197^{* *} \\
(.073)\end{array}$ & $\begin{array}{l}-.198^{* * *} \\
(.073)\end{array}$ & $\begin{array}{l}-.196^{* *} \\
(.076)\end{array}$ & $\begin{array}{l}-.175^{*} \\
(.076)\end{array}$ & $\begin{array}{l}-.117 \\
(.108) \\
-.128\end{array}$ & $\begin{array}{l}-.598^{* *} \\
(.156) \\
-.702\end{array}$ \\
\hline \#Deals t-1 & $\begin{array}{l}.125^{* * *} \\
(.022)\end{array}$ & $\begin{array}{l}.123^{* * *} \\
(.022)\end{array}$ & $\begin{array}{l}.121^{* * *} \\
(.022)\end{array}$ & $\begin{array}{l}.112^{* * *} \\
(.023)\end{array}$ & $\begin{array}{l}.103^{* * *} \\
(.023)\end{array}$ & $\begin{array}{l}.075+ \\
(.043) \\
.085\end{array}$ & $\begin{array}{l}.131^{* * *} \\
(.018) \\
.192\end{array}$ \\
\hline Gov. effectiveness & $\begin{array}{l}.003 \\
(.003)\end{array}$ & $\begin{array}{l}.002 \\
(.003)\end{array}$ & $\begin{array}{l}.003 \\
(.003)\end{array}$ & $\begin{array}{l}.005 \\
(.003)\end{array}$ & $\begin{array}{l}.003 \\
(.004)\end{array}$ & $\begin{array}{l}.008 \\
(.007) \\
.009\end{array}$ & $\begin{array}{l}.005 \\
(.003) \\
.007\end{array}$ \\
\hline Mktcap & & $\begin{array}{l}.002^{*} \\
(.000)\end{array}$ & & & $\begin{array}{l}.002^{*} \\
(.001)\end{array}$ & $\begin{array}{l}.003^{*} \\
(.001) \\
.005\end{array}$ & $\begin{array}{l}.008^{*} \\
(.003) \\
.014\end{array}$ \\
\hline Natural resources & & & $\begin{array}{l}.035^{* * *} \\
(.005)\end{array}$ & & $\begin{array}{l}.009^{*} \\
(.003)\end{array}$ & $\begin{array}{l}.013^{*} \\
(.005) \\
.016\end{array}$ & $\begin{array}{l}.007^{+} \\
(.003) \\
.012\end{array}$ \\
\hline Patents & & & & $\begin{array}{l}.090 \\
(.055)\end{array}$ & $\begin{array}{l}.047 \\
(.058)\end{array}$ & $\begin{array}{l}.047 \\
(.074) \\
.055\end{array}$ & $\begin{array}{l}.202^{* *} \\
(.142) \\
.306\end{array}$ \\
\hline Log likelihood & -978.33 & -966.28 & -977.12 & -977.46 & -934.23 & -590.13 & -552.05 \\
\hline Wald Chi-square & $103.68^{* * *}$ & $112.65^{* * *}$ & $106.72^{* * *}$ & $103.85^{* * * *}$ & $113.85^{* * *}$ & $46.90^{* * * *}$ & $66.07^{* * *}$ \\
\hline Sample size & 1053 & 1053 & 1053 & 1053 & 1053 & 484 & 569 \\
\hline
\end{tabular}

a Figures in cells of Model 6 are estimated coefficient/standard deviation/average marginal effect.

* $p<.05$.

** $p<.01$.

${ }^{* * *} p<.001$.

$+p<.10$. 
rather than as constraint. This might be due to the nature of natural resource acquisitions. Given a large scale of investment, EMFs prefer high host government effectiveness to better secure their international acquisitions and legally protect their long-term interests (Kamaly, 2007; Peng et al., 2008).

In terms of the effects of control variables, as shown in Model 5 of Tables 5 and 6, the coefficients of Home Mktcap, Foreign reserves and \#Deals at $t-1$ are positive and significant $(p<.001, p<.05)$, indicating that EMFs are likely to undertake more M\&As in both developed and developing markets when their home countries have bigger financial market size, have higher foreign reserves and when they undertook more acquisitions in the previous year. Moreover, the coefficients of Cultural distance is significant $(p<.05)$ but negative only in the setting of developing markets. Therefore, EMFs are likely to undertake more M\&As in developing markets when these markets have small cultural distance with home countries of these acquiring firms.

To conclude, our empirical results show that factors affecting the level of cross-border M\&As by EMFs in developed markets are different from those in developing markets. The resource dependence perspective for cross-border M\&As by EMFs and the moderating effects of host government effects on the M\&A logic are fully supported in the setting of developed markets and, to a large extent supported in the setting of developing markets.

\subsection{Sensitivity analyses and robustness check}

To test whether Chinese firms are different from other EMFs, we focused on subsample of cross-border M\&As initiated by Chinese firms and compared the results to those reported in Tables 5 and 6. As shown in Table 7, we found that there are more differences than similarities when comparing Chinese cross-border M\&As with those M\&As by other EMFs. Similar to other EMFs, Hypotheses 1 to 3 are supported in the subsample of Chinese M\&As in the setting of developed markets. Nevertheless, Chinese firms are different from other EMFs in many other aspects. In terms of the moderating effect of host government effectiveness in developed markets, the coefficients of Mktcap, Natural resources and Patents are positive and significant $(p<.05$ and $p<.01)$ under high government effectiveness. Therefore, host government effectiveness in developed countries positively, not negatively, moderates the relationships between Chinese cross-border M\&As and the size of financial market and the richness of natural resources and strategic assets of developed countries. In the setting of developing markets, none of the main effects of Hypotheses 1 to 3 are significant for Chinese M\&As. As to the moderating effects of host government effectiveness in developing markets, the coefficient of Mktcap and Patents are positive and significant $(p<.05$ and $p<.01)$ under high government effectiveness. As a result, host government effectiveness in developing countries positively rather than negatively moderates the relationships between Chinese cross-border M\&As and the size of host market and the richness of strategic assets of developing markets. According to our empirical results above, we believe that generalization of Chinese cross-border M\&As to other EMFs or vice versa needs to be cautious.

Since government ownership has important implications for EMFs in their international acquisitions (Deng, 2013), we examined

Table 7

Negative binomial regression analysis of the No. of CBMAs by Chinese firms in different markets, 2000-2012.

\begin{tabular}{|c|c|c|c|c|c|c|}
\hline \multirow[t]{2}{*}{ Independent variables } & \multicolumn{3}{|c|}{ Developed market } & \multicolumn{3}{|c|}{ Developing market } \\
\hline & $\begin{array}{l}\text { All main } \\
\text { effects }\end{array}$ & $\begin{array}{l}\text { High government } \\
\text { effectiveness }\end{array}$ & $\begin{array}{l}\text { Low government } \\
\text { effectiveness }\end{array}$ & $\begin{array}{l}\text { All main } \\
\text { effects }\end{array}$ & $\begin{array}{l}\text { High government } \\
\text { effectiveness }\end{array}$ & $\begin{array}{l}\text { Low government } \\
\text { effectiveness }\end{array}$ \\
\hline Intercept & $\begin{array}{l}-20.685^{* * *} \\
(3.391)\end{array}$ & $\begin{array}{l}-18.854^{* *} \\
(7.251)\end{array}$ & $\begin{array}{l}-30.904^{* * * *} \\
(6.508)\end{array}$ & $\begin{array}{l}-6.657 \\
(4.517)\end{array}$ & $\begin{array}{l}-31.245^{*} \\
(14.173)\end{array}$ & $\begin{array}{l}5.324 \\
(8.671)\end{array}$ \\
\hline Home GDPgrowth & $\begin{array}{l}.026 \\
(.059)\end{array}$ & $\begin{array}{l}.034 \\
(.074) \\
.093\end{array}$ & $\begin{array}{l}.016 \\
(.011) \\
.049\end{array}$ & $\begin{array}{l}.094 \\
(.102)\end{array}$ & $\begin{array}{l}.011 \\
(.138) \\
.006\end{array}$ & $\begin{array}{l}.250 \\
(.193) \\
.184\end{array}$ \\
\hline Home Mktcap & $\begin{array}{l}.002 \\
(.002)\end{array}$ & $\begin{array}{l}.002 \\
(.003) \\
.005\end{array}$ & $\begin{array}{l}.005 \\
(.003) \\
.014\end{array}$ & $\begin{array}{l}.009^{*} \\
(.003)\end{array}$ & $\begin{array}{l}.009^{*} \\
(.003) \\
.004\end{array}$ & $\begin{array}{l}.014^{+} \\
(.007) \\
.008\end{array}$ \\
\hline Foreign Reserve & $\begin{array}{l}.886^{* * * *} \\
(.239)\end{array}$ & $\begin{array}{l}.845^{*} \\
(.322) \\
2.550\end{array}$ & $\begin{array}{l}1.604^{* * *} \\
(.313) \\
4.524\end{array}$ & $\begin{array}{l}.142 \\
(.434)\end{array}$ & $\begin{array}{l}.235 \\
(.587) \\
.112\end{array}$ & $\begin{array}{l}1.137 \\
(.720) \\
.689\end{array}$ \\
\hline Cultural distance & $\begin{array}{l}-.306^{*} \\
(.108)\end{array}$ & $\begin{array}{l}-.325^{*} \\
(.130) \\
-1.124\end{array}$ & $\begin{array}{l}.241 \\
(.171) \\
.702\end{array}$ & $\begin{array}{l}-.127 \\
(.251)\end{array}$ & $\begin{array}{l}-2.236^{*} \\
(.605) \\
-1.089\end{array}$ & $\begin{array}{l}-.664 \\
(.821) \\
-.416\end{array}$ \\
\hline \#Deals t-1 & $\begin{array}{l}.023 \\
(.016)\end{array}$ & $\begin{array}{l}.003 \\
(.031) \\
.009\end{array}$ & $\begin{array}{l}.057 \\
(.078) \\
.150\end{array}$ & $\begin{array}{l}.036 \\
(.121)\end{array}$ & $\begin{array}{l}.003 \\
(.151) \\
.002\end{array}$ & $\begin{array}{l}.204 \\
(.205) \\
.113\end{array}$ \\
\hline Gov. effectiveness & $\begin{array}{l}.017 \\
(.015)\end{array}$ & $\begin{array}{l}.014 \\
(.063) \\
.052\end{array}$ & $\begin{array}{l}.047^{*} \\
(.022) \\
.121\end{array}$ & $\begin{array}{l}.019 \\
(.012)\end{array}$ & $\begin{array}{l}.028 \\
(.026) \\
.015\end{array}$ & $\begin{array}{l}-.015 \\
(.059) \\
-.009\end{array}$ \\
\hline Mktcap & $\begin{array}{l}.008^{* *} \\
(.002)\end{array}$ & $\begin{array}{l}.008^{*} \\
(.002) \\
.022\end{array}$ & $\begin{array}{l}.010 \\
(.006) \\
.035\end{array}$ & $\begin{array}{l}.005 \\
(.003)\end{array}$ & $\begin{array}{l}.026^{*} \\
(.012) \\
.014\end{array}$ & $\begin{array}{l}.008 \\
(.017) \\
.005\end{array}$ \\
\hline Natural resources & $\begin{array}{l}.067^{* *} \\
(.012)\end{array}$ & $\begin{array}{l}.076 \\
(.019) \\
.260\end{array}$ & $\begin{array}{l}.356 \\
(.293) \\
.921\end{array}$ & $\begin{array}{l}.012 \\
(.016)\end{array}$ & $\begin{array}{l}.073^{+} \\
(.036) \\
.035\end{array}$ & $\begin{array}{l}.013 \\
(.050) \\
.008\end{array}$ \\
\hline Patents & $\begin{array}{l}.175^{*} \\
(.043)\end{array}$ & $\begin{array}{l}.185^{*} \\
(.076) \\
.576\end{array}$ & $\begin{array}{l}.141 \\
(.432) \\
.382\end{array}$ & $\begin{array}{l}.310 \\
(.376)\end{array}$ & $\begin{array}{l}2.948^{* *} \\
(.723) \\
1.521\end{array}$ & $\begin{array}{l}.146 \\
(.154) \\
.093\end{array}$ \\
\hline Log likelihood & -265.80 & -179.17 & -96.16 & -125.86 & -88.24 & -48.74 \\
\hline LR Chi-square & $121.61^{* * *}$ & $83.63^{* * *}$ & $84.69^{* * *}$ & 13.14 & $25.63^{* * *}$ & 12.67 \\
\hline Sample size & 143 & 95 & 48 & 156 & 84 & 72 \\
\hline
\end{tabular}

Figures in cells of high and low government effectiveness are estimated coefficient/standard deviation/average marginal effect.

${ }^{*} p<0.05$.

** $p<0.01$.

${ }^{* * *} p<0.001$

$+p<.10$. 
Table 8

Negative binomial regression analysis of the No. of CBMAs by government-owned firms in different markets, $2000-2012$.

\begin{tabular}{|c|c|c|c|c|c|c|}
\hline \multirow[t]{2}{*}{ Independent variables } & \multicolumn{3}{|c|}{ Developed market } & \multicolumn{3}{|c|}{ Developing market } \\
\hline & $\begin{array}{l}\text { All main } \\
\text { effects }\end{array}$ & $\begin{array}{l}\text { High government } \\
\text { effectiveness }\end{array}$ & $\begin{array}{l}\text { Low government } \\
\text { effectiveness }\end{array}$ & $\begin{array}{l}\text { All main } \\
\text { effects }\end{array}$ & $\begin{array}{l}\text { High government } \\
\text { effectiveness }\end{array}$ & $\begin{array}{l}\text { Low government } \\
\text { effectiveness }\end{array}$ \\
\hline Intercept & $\begin{array}{l}-23.454^{* * *} \\
(4.587)\end{array}$ & $\begin{array}{l}-11.036 \\
(8.302)\end{array}$ & $\begin{array}{l}-22.882^{* * * *} \\
(3.799)\end{array}$ & $\begin{array}{l}-3.228 \\
(2.787)\end{array}$ & $\begin{array}{l}-4.937 \\
(3.716)\end{array}$ & $\begin{array}{l}-3.107 \\
(2.959)\end{array}$ \\
\hline Home GDPgrowth & $\begin{array}{l}.028 \\
(.026)\end{array}$ & $\begin{array}{l}.048 \\
(.040) \\
.019\end{array}$ & $\begin{array}{l}.007 \\
(.033) \\
.015\end{array}$ & $\begin{array}{l}.016 \\
(.043)\end{array}$ & $\begin{array}{l}.003 \\
(.036) \\
.001\end{array}$ & $\begin{array}{l}.126^{* * * *} \\
(.030) \\
.061\end{array}$ \\
\hline Home Mktcap & $\begin{array}{l}.002 \\
(.002)\end{array}$ & $\begin{array}{l}.002 \\
(.003) \\
.001\end{array}$ & $\begin{array}{l}.002 \\
(.004) \\
.003\end{array}$ & $\begin{array}{l}.003 \\
(.003)\end{array}$ & $\begin{array}{l}.005 \\
(.004) \\
.001\end{array}$ & $\begin{array}{l}.006^{* * *} \\
(.001) \\
.003\end{array}$ \\
\hline Foreign Reserve & $\begin{array}{l}1.053^{* * *} \\
(.239)\end{array}$ & $\begin{array}{l}1.036^{* * *} \\
(.274) \\
.323\end{array}$ & $\begin{array}{l}1.553^{* * *} \\
(.308) \\
2.925\end{array}$ & $\begin{array}{l}.387^{+} \\
(.229)\end{array}$ & $\begin{array}{l}.130 \\
(.286) \\
.042\end{array}$ & $\begin{array}{l}.416^{+} \\
(.234) \\
.204\end{array}$ \\
\hline Cultural distance & $\begin{array}{l}.125 \\
(.104)\end{array}$ & $\begin{array}{l}.113 \\
(.099) \\
.031\end{array}$ & $\begin{array}{l}.209 \\
(.174) \\
.412\end{array}$ & $\begin{array}{l}.106 \\
(.144)\end{array}$ & $\begin{array}{l}.046 \\
(.182) \\
.020\end{array}$ & $\begin{array}{l}-1.898^{*} \\
(.784) \\
-.963\end{array}$ \\
\hline \#Deals t-1 & $\begin{array}{l}.091^{*} \\
(.035)\end{array}$ & $\begin{array}{l}.107^{*} \\
(.043) \\
.030\end{array}$ & $\begin{array}{l}.054 \\
(.075) \\
.110\end{array}$ & $\begin{array}{l}.277^{+} \\
(.144)\end{array}$ & $\begin{array}{l}.005 \\
(.204) \\
.001\end{array}$ & $\begin{array}{l}.386^{* * *} \\
(.094) \\
.163\end{array}$ \\
\hline Gov. effectiveness & $\begin{array}{l}.033^{*} \\
(.016)\end{array}$ & $\begin{array}{l}-.030 \\
(.053) \\
-.013\end{array}$ & $\begin{array}{l}.048^{*} \\
(.021) \\
.097\end{array}$ & $\begin{array}{l}-.011 \\
(.010)\end{array}$ & $\begin{array}{l}.006 \\
(.019) \\
.002\end{array}$ & $\begin{array}{r}-.045 \\
(.055) \\
-.020\end{array}$ \\
\hline Mktcap & $\begin{array}{l}.001 \\
(.001)\end{array}$ & $\begin{array}{l}.001 \\
(.002) \\
.001\end{array}$ & $\begin{array}{l}.002 \\
(.004) \\
.005\end{array}$ & $\begin{array}{l}.002 \\
(.002)\end{array}$ & $\begin{array}{l}.001 \\
(.003) \\
.001\end{array}$ & $\begin{array}{l}.004 \\
(.011) \\
.002\end{array}$ \\
\hline Natural resources & $\begin{array}{l}.039^{* *} \\
(.008)\end{array}$ & $\begin{array}{l}.023 \\
(.062) \\
.007\end{array}$ & $\begin{array}{l}.050^{\text {**** }} \\
(.012) \\
.108\end{array}$ & $\begin{array}{l}.003 \\
(.013)\end{array}$ & $\begin{array}{l}.027 \\
(.024) \\
.007\end{array}$ & $\begin{array}{l}.036^{*} \\
(.017) \\
.017\end{array}$ \\
\hline Patents & $\begin{array}{l}-.232 \\
(.287)\end{array}$ & $\begin{array}{l}.111 \\
(.183) \\
.034\end{array}$ & $\begin{array}{l}-.701 \\
(.435) \\
-1.417\end{array}$ & $\begin{array}{l}.057 \\
(.238)\end{array}$ & $\begin{array}{l}.314 \\
(.296) \\
.101\end{array}$ & $\begin{array}{l}2.096 \\
(.831) \\
1.092\end{array}$ \\
\hline $\begin{array}{l}\text { Log likelihood } \\
\text { LR Chi-square }\end{array}$ & $\begin{array}{l}-368.81 \\
178.73^{* * *}\end{array}$ & $\begin{array}{l}-238.60 \\
106.02^{* * *}\end{array}$ & $\begin{array}{l}-124.89 \\
60.18^{* * *}\end{array}$ & $\begin{array}{l}-222.98 \\
18.81^{*}\end{array}$ & $\begin{array}{l}-156.89 \\
14.24\end{array}$ & $\begin{array}{l}-89.12 \\
26.75^{*}\end{array}$ \\
\hline Sample size & 371 & 228 & 143 & 339 & 233 & 106 \\
\hline
\end{tabular}

Figures in cells of high and low government effectiveness are estimated coefficient/standard deviation/average marginal effect.

${ }^{*} p<.05$.

*** $p<.01$.

${ }^{* * *} p<.001$.

$+p<.10$.

those M\&As initiated by government-owned firms from emerging economies and tested whether our hypotheses would be supported. As shown in Table 8, in the setting of developed markets, only the coefficient of Natural resources is positive and significant $(p<.01)$ so that Hypothesis 2 is supported. In the setting of developing markets, none of main effects (Hypotheses 1 to 3 ) are supported. In terms of moderating effects of government effectiveness of host markets, the coefficients of Natural resources is positive and significant $(p<.01)$ in the subsample of low government effectiveness in developed markets. Thus, Hypotheses $5 \mathrm{a}$ is supported. Likewise, as the coefficients of Natural resources and Patents are positive and significant $(p<.05$ and $p<.01)$ in the subsample of low government effectiveness in developing markets, Hypothesis $5 \mathrm{a}$ and $5 \mathrm{~b}$ are supported. To conclude, the results of cross-border M\&As by government-owned EMFs are not exactly the same as those reported in Tables 5 and 6. Our empirical results verify that the government ownership of acquiring firms from emerging markets is a critical factor affecting overseas M\&A decisions (Hurst, 2011; Xia et al., 2013). Particularly, our results indicate that cross-border M\&As by government-owned EMFs are most likely to be driven by the motive of seeking natural resources and the weak government effectiveness of host market will strengthen this motive.

One of the deficiencies with prior studies in which aggregated data were used (e.g., Buckley et al., 2007) is that aggregated data might conceal what can be observed based on finer industry classification. However, M\&As may vary significantly with industries (Bower, 2001). For example, variables such as natural resources may be more sensitive to resource-intensive industries, but they will not show much statistical significance in pooled samples where all industries are included. In response, we used the first 2-digit SIC codes of acquiring firms to generate two subsamples: "Hi-Tech industry" and "Service industry." Given that the results of "Service industry" are similar to those reported in Tables 5 and 6, we only report how industrial differences from Hi-Tech industry affect the level of cross-border M\&As by EMFs. While the role of strategic assets is sensitive in Hi-Tech industry, the results shown in Table 9 indicate that Patents is both positive and significant $(p<.01)$ in developed and developing markets, which show stronger support than the insignificance of Patents in developing markets (see Table 6).

We further performed several sensitivity tests to check the robustness of our results. First, we ran the analysis of subsample with countries with low frequency (e.g., fewer than five M\&A deals). The results were similar as those presented in Tables 5 and 6. Moreover, we tried different measures of some critical variables in our model. Regarding the measure of "strategic asset", we replaced Patents with another popular measure "R\&D spending amount" in the World Development Indicators Database, and the result was positive and similar to Patents. In the same vein, we replaced Gov. effectiveness with other measures of indicators such as quality of regulation and the rule of law, as included in Kaufmann et al. (2010). We found that they were also significant and showed similar results as those reported in Tables 5 and 6 . Overall, our sensitivity analyses indicated that the results of our hypothesis testing were robust, thereby validating our empirical findings. 
Table 9

Negative binomial regression of the No. of CBMAs by hi-tech industry, 2000-2012.

\begin{tabular}{|c|c|c|c|c|c|c|}
\hline \multirow[t]{2}{*}{ Independent variables } & \multicolumn{3}{|c|}{ Developed market } & \multicolumn{3}{|c|}{ Developing market } \\
\hline & $\begin{array}{l}\text { All main } \\
\text { effects }\end{array}$ & $\begin{array}{l}\text { High government } \\
\text { effectiveness }\end{array}$ & $\begin{array}{l}\text { Low government } \\
\text { effectiveness }\end{array}$ & $\begin{array}{l}\text { All main } \\
\text { effects }\end{array}$ & $\begin{array}{l}\text { High government } \\
\text { effectiveness }\end{array}$ & $\begin{array}{l}\text { Low government } \\
\text { effectiveness }\end{array}$ \\
\hline Intercept & $\begin{array}{l}-15.526^{* * *} \\
(1.568)\end{array}$ & $\begin{array}{l}-14.691^{* * *} \\
(3.518)\end{array}$ & $\begin{array}{l}-11.880^{* * *} \\
(3.206)\end{array}$ & $\begin{array}{l}-5.951^{*} \\
(2.057)\end{array}$ & $\begin{array}{l}-4.729 \\
(2.417)\end{array}$ & $\begin{array}{l}-7.691 \\
(4.617)\end{array}$ \\
\hline Home GDPgrowth & $\begin{array}{l}.009 \\
(.014)\end{array}$ & $\begin{array}{l}.012 \\
(.020) \\
.017\end{array}$ & $\begin{array}{l}.005 \\
(.019) \\
.017\end{array}$ & $\begin{array}{l}.006 \\
(.019)\end{array}$ & $\begin{array}{l}.015 \\
(.023) \\
.021\end{array}$ & $\begin{array}{l}-.035 \\
(.033) \\
-.038\end{array}$ \\
\hline Home Mktcap & $\begin{array}{l}.002 \\
(.001)\end{array}$ & $\begin{array}{l}.002 \\
(.001) \\
.003\end{array}$ & $\begin{array}{l}.001 \\
(.002) \\
.003\end{array}$ & $\begin{array}{l}.003+ \\
(.002)\end{array}$ & $\begin{array}{l}.003+ \\
(.002) \\
.004\end{array}$ & $\begin{array}{l}.005+ \\
(.003) \\
.005\end{array}$ \\
\hline Foreign Reserve & $\begin{array}{l}1.191^{* * *} \\
(.121)\end{array}$ & $\begin{array}{l}1.314^{* * *} \\
(.162) \\
1.968\end{array}$ & $\begin{array}{l}.907^{* *} \\
(.267) \\
2.626\end{array}$ & $\begin{array}{l}.548^{*} \\
(.287)\end{array}$ & $\begin{array}{l}.421^{*} \\
(.210) \\
.489\end{array}$ & $\begin{array}{l}.859^{*} \\
(.426) \\
.973\end{array}$ \\
\hline Cultural distance & $\begin{array}{l}-.187^{* *} \\
(.053)\end{array}$ & $\begin{array}{l}-.218^{* *} \\
(.065) \\
-.322\end{array}$ & $\begin{array}{l}-.076 \\
(.091) \\
-.208\end{array}$ & $\begin{array}{l}-.171 \\
(.104)\end{array}$ & $\begin{array}{l}-.113 \\
(.122) \\
-.125\end{array}$ & $\begin{array}{l}-.571^{*} \\
(.254) \\
-.593\end{array}$ \\
\hline \#Deals t-1 & $\begin{array}{l}.029^{* * *} \\
(.004)\end{array}$ & $\begin{array}{l}.059^{* * *} \\
(.008) \\
.086\end{array}$ & $\begin{array}{l}.017^{*} \\
(.007) \\
.052\end{array}$ & $\begin{array}{l}.174^{*} \\
(.062)\end{array}$ & $\begin{array}{l}.120^{*} \\
(.061) \\
.144\end{array}$ & $\begin{array}{l}.187^{*} \\
(.086) \\
190\end{array}$ \\
\hline Gov. effectiveness & $\begin{array}{l}-.009 \\
(.007)\end{array}$ & $\begin{array}{l}-.026 \\
(.031) \\
-.042\end{array}$ & $\begin{array}{l}-.007 \\
(.013) \\
-.022\end{array}$ & $\begin{array}{l}-.001 \\
(.005)\end{array}$ & $\begin{array}{l}.001 \\
(.009) \\
.002\end{array}$ & $\begin{array}{l}-.024 \\
(.023) \\
-.025\end{array}$ \\
\hline Mktcap & $\begin{array}{l}.006^{* * *} \\
(.001)\end{array}$ & $\begin{array}{l}.005^{* * *} \\
(.001) \\
.008\end{array}$ & $\begin{array}{l}.007^{* * *} \\
(.002) \\
.022\end{array}$ & $\begin{array}{l}.003^{+} \\
(.002)\end{array}$ & $\begin{array}{l}.003^{+} \\
(.002) \\
.004\end{array}$ & $\begin{array}{l}.006 \\
(.004) \\
.006\end{array}$ \\
\hline Natural resources & $\begin{array}{l}.012 \\
(.008)\end{array}$ & $\begin{array}{l}.009 \\
(.008) \\
.014\end{array}$ & $\begin{array}{l}.214 \\
(.112) \\
.598\end{array}$ & $\begin{array}{l}.010^{*} \\
(.005)\end{array}$ & $\begin{array}{l}.011^{*} \\
(.005) \\
.018\end{array}$ & $\begin{array}{l}.012^{* *} \\
(.003) \\
.013\end{array}$ \\
\hline Patents & $\begin{array}{l}.476^{* *} \\
(.148)\end{array}$ & $\begin{array}{l}.418^{* *} \\
(.135) \\
.532\end{array}$ & $\begin{array}{l}.615^{* *} \\
(.125) \\
1.721\end{array}$ & $\begin{array}{l}.183^{* *} \\
(.035)\end{array}$ & $\begin{array}{l}.171^{*} \\
(.083) \\
.188\end{array}$ & $\begin{array}{l}.297^{* *} \\
(.052) \\
.299\end{array}$ \\
\hline $\begin{array}{l}\text { Log likelihood } \\
\text { LR Chi-square }\end{array}$ & $\begin{array}{l}-1136.28 \\
761.81^{* * *}\end{array}$ & $\begin{array}{l}-732.93 \\
404.03^{* * * *}\end{array}$ & $\begin{array}{l}-387.12 \\
317.90^{* * *}\end{array}$ & $\begin{array}{l}-632.33 \\
88.99^{* * * *}\end{array}$ & $\begin{array}{l}-414.17 \\
38.32^{* * *}\end{array}$ & $\begin{array}{l}-217.13 \\
55.51^{* * * *}\end{array}$ \\
\hline Sample size & 811 & 555 & 256 & 588 & 374 & 214 \\
\hline
\end{tabular}

Figures in cells of high and low government effectiveness are estimated coefficient/standard deviation/average marginal effect.

${ }^{*} p<0.05$.

** $p<0.01$.

${ }^{* * *} p<0.001$

$+p<.10$.

\section{Discussion and conclusions}

With an increasing importance of EMFs in international investment (Deng, 2012; UNCTAD, 2014; Wang et al., 2012), this study focuses on major determinants of cross-border M\&As from emerging economies in different destinations in the resource dependence logic of M\&As (or simply the M\&A logic). Our results suggest that a higher level of resource and market availability in host countries increases the intensity of international acquisitions by EMFs. In addition, we find that facing lower host government effectiveness EMFs are more likely to respond to EMNC-host country interdependence pressures to engage in cross-border M\&As, indicating that host government effectiveness is indeed a boundary condition of the M\&A logic in global settings. Overall, we explore the moderating effects of government effectiveness, as a consequence of institutional systems in a host nation, while linking them through the common thread of the resource dependence perspective. In so doing, we contribute to the extant literature in several distinct ways.

\subsection{Contributions}

First, this study offers a resource dependence perspective to understand international acquisitions from emerging economies by focusing on important market and resource drivers. Our findings indicate that resource availability in host countries is an important antecedent of cross-border M\&As by EMFs and RDT offers critical insights to guide additional empirical research in global settings. Our findings are important because there is a limited amount of empirical work explicitly extending and testing RDT and its central tenets in the comparative literature on the preconditions of cross-border M\&As by EMFs. However, this explanation offers useful insights of a broader picture of the relationships between resource dependence and cross-border $M \& A s$, as revealed in our study.

Second, RDT has been criticized for its ambiguities regarding boundary conditions, which constrains its theoretical advancement (Hillman et al., 2009). Our study addresses this limitation by identifying host government effectiveness as a moderator to explore the boundary conditions of the EMF-host country interdependence effect. In this sense, our study provides a refinement to enhance the precision of the theoretical predictions (Boyd, Takacs, Hitt, Bergh, \& Ketchen, 2012). Our findings indicate that the predictive power of the M\&A logic is influenced by host government effectiveness when an EMF is tied to the host country via ownership of acquired local firms. On top of that, government effectiveness may be a coercive force that compels firms to take actions to adapt themselves to both environmental and government dependencies. Such institutional force within a host nation may also result in isomorphism (DiMaggio \& Powell, 1983) and influence what form of dependency reducing strategies the EMFs use (Peng et al., 2008). This interactive approach adopted in this study has not been specified in previous empirical studies.

Third, this study complements existing knowledge of the internationalization of EMFs via cross-border M\&As. Prior M\&A studies accounted for the international expansion of EMFs by 
examining their capabilities and inside conditions (i.e., domestic market) (Deng, 2012; Guillen \& Garcia-Canal, 2009; Luo \& Wang, 2012). Our study focuses on conditions outside EMFs for resource constraint absorption by introducing the M\&A logic and its boundary conditions. Our study also supplements the call for more studies to understand OFDI as an escape response to environmental constraints in the home country (Witt \& Lewin, 2009). Given their less munificent home country environments (Heeley et al., 2006), resource availability abroad is particularly important for EMFs. In this sense, our study takes a significant step toward eliminating this gap by adopting the M\&A logic to clarify how appealing conditions in a host nation as pulling factors in influencing the intensity of cross-border M\&As by EMFs. In so doing, we shed light on the debate regarding applicability of Western theories (e.g., RDT) in emerging market settings, as we have not only revealed the differences but more importantly the potential for bridges (Deng, 2013; Hoskisson et al., 2013).

Fourth, we found differences in the determinants of crossborder M\&As by EMFs in developed and developing countries, which are in line with the predications of resource dependence arguments. In the setting of developed markets, all of our hypotheses are supported, whereas in developing markets our hypotheses are partially supported. If we take into account of the resource availability in each host setting, these disparities are not surprising. For example, in developed markets (Model 5 in Table 5), the magnitude of Patent is stronger than Natural resources, which means that an increased importance for knowledge assets over natural resources" appears in the sample of developed markets. But in the context of developing markets (Model 5 in Table 6), the main effect of Patent is not significant but the main effect of Natural resources is significant. This may be because in developing markets there is general lack of innovation-based knowledge so that strategic asset is not as abundant as their natural resources. As a result, strategic asset seeking motive by EMFs is not significantly supported (although positive) in developing markets. With regard to the moderating effects of host government effectiveness on the M\&A logic, we also find differences the two types of destinations. In developing countries, contradictory to our prediction, government effectiveness positively, not negatively, moderates the relationship between the number of cross-border M\&As and the level of natural resources of host markets. This result could be explained by the nature of natural resource acquisition. Given a relatively large scale of equity commitments, EMFs prefer high government effectiveness in host developing countries to legally protect their long-term interests (Kamaly, 2007; Peng et al., 2008). Our findings show that the M\&A logic is fully supported in the settings of developed markets and to a large extent, supported in the setting of developing markets. The empirical results are largely consistent with previous studies of applying Western theories into emerging economies. For instance, in examining China's state-owned OFDI from 2003 to 2008, Hurst (2011) found that the OLI paradigm provides an excellent framework for the determinants of Chinese state-owned enterprise investment in developed countries, but needs refinement for developing countries.

Furthermore, our results also indicate that Chinese firms may not necessarily act the same way as other EMFs. In terms of the moderating effect of host government effectiveness in the setting developed markets, Chinese investors are different from other EMFs in that host government effectiveness positively rather than negatively moderates the relationships between Chinese crossborder M\&As and the size of financial market, the richness of natural resources and strategic assets of developed countries. In the setting of developing markets, Chinese firms are also different from other EMFs in that none of the main effects are significant. In terms of the moderating effects, host government effectiveness in developing countries positively, not negatively, moderates the relationships between Chinese cross-border M\&As and the size of host market and the richness of strategic assets of developing markets. Our results show that some resource dependence arguments may hold for some specific countries, but are not generalizable across emerging economies as a whole. Therefore, we contend that generalization of Chinese cross-border M\&A findings to other EMFs or vice versa should be done cautiously.

Our findings also have important implications for managers and policy makers in both emerging and developed economies. In most of emerging markets, privatization and liberalization have generally created an environment that increases EMFs' autonomy and intensify domestic competition (Hoskisson et al., 2013). When EMFs are unable to absorb resource constraints in the home market, they are likely to conduct cross-border M\&As as an avoidance (escape) strategy (Kumarasamy et al., 2012). Our study implies that with increasing competition and resource uncertainty in the home market, a more admirable host country environment will further trigger EMF internationalization. The key reason is that EMFs without much home resource backing are increasingly more dependent on overseas markets for constraint absorption. This study also has useful implications for managers to understand M\&A issues from a resource dependence lens. Markets and resources in the host country are two basic determinants of cross-border M\&As, however, such antecedents are negatively moderated by host government effectiveness. Therefore, while engaging overseas acquisitions, managers should not only rely on the resource availability as the only criterion to make M\&A decisions, but also carefully evaluate the impact of host country's institutional environment so as to better understand when and how to leverage M\&As for strategic advantages.

\subsection{Limitations and future research directions}

There are several limitations of this study that can be regarded as opportunities for future research. First, we have limited our theorizing to the resource dependence literature. However, resource dependence is not the only explanation for cross-border M\&As and other theoretical approaches also exist (Shimizu, 2007; Chen \& Young, 2010). For example, M\&As can be driven by the empire building motivation from an agency theory perspective rather than managing environmental uncertainty from the resource dependence lens. A comparison of power-dependence changes and other organizational and environmental changes beyond RDT explanations merits further examination. Moreover, we focus on the resource dependences in a host country to explain $M \& A$ activities by EMFs. To obtain a more complete understanding, one should explore how environmental dependences in a home country affect overseas M\&As. Home country-based factors are likely to have a "push" effect on M\&As, whereas host countrybased factors will have a "pull" effect. These effects by home and host countries are likely to coexist during the internationalization process (Buckley et al., 2012). Ideally, one should study both. In the same vein, we measure strategic assets simply by patents (plus a robust test of R\&D spending amount). However, as strategic assets also include brands and supplier networks, future studies should include "brand" or "marketing skill" measures, which might account for the inconsistent results for our hypothesis of strategic assets. Furthermore, although M\&As represents the most complete form of constraint absorption, EMFs may resort to other partial forms of constraint absorption (e.g., greenfield investments, strategic alliance, and JVs) to deal with environmental dependencies. Future research may consider how various dependence conditions drive different types of constraint absorption strategy and specify the conditions under which one strategy will dominate. Finally, this paper only focuses on the macro-level determinants of cross-border M\&As by EMFs. Other levels of 
analysis and particularly those truly micro-level factors such as individual-level and group-level determinants are worthwhile to explore in the future; such macro-micro linkage investigations are more promising in getting a complete picture on the surge of crossborder M\&As by EMFs.

Despite these limitations, our study makes significant contributions by conducting a systematic comparative study of crossborder M\&As by EMFs involving a broad range of emerging economies in both developed and developing markets within the resource dependence logic of M\&As. Building on the M\&A logic model proposed in this research, more comparative investigations could increase our understanding of the extant literature by providing generalizable and critical evidence. In essence, crossborder M\&As by EMFs present numerous unique opportunities that could enrich and extend mainstream theory (e.g., RDT) in terms of bringing context more explicitly into the research (Child, 2009; Xu \& Meyer, 2013), a topic of central concern to management and international business scholars. Overall, beyond the dyadic interdependence between EMFs and host markets, this study has taken a step to theorize about a triadic relationship by introducing host government effectiveness as a boundary condition of the resource dependence perspective. We believe that our study provides a point of departure from prior studies and will inspire future research to better understand the resource dependence logic of M\&As in global settings.

\section{Acknowledgements}

We are grateful to the Editor-in-Chief Professor Pervez Ghauri and the two anonymous reviewers for providing detailed and constructive feedback throughout the review process. This research was partially supported by the Monte Ahuja Endowment Fund for Global Business at Cleveland State University.

\section{References}

Abrami, R., Kirby, W., \& McFarlan, W. (2014). Why China can't innovate. Harvard Business Review, March, 107-111.

Allison, P. (1995). Survival analysis using the SAS system: A practical guide. Cary, NC: SAS Institute Inc.

Antkiewicz, A., \& Whalley, J. (2007). Recent Chinese buyout activity and the implications for wider global investment rules. Canadian Public Policy, 33, 207-226.

Bhagata, S., Malhotrab, S., \& Zhu, P. (2011). Emerging country cross-border acquisitions: Characteristics, acquirer returns and cross-sectional determinants. Emerging Markets Review, 12(3), 250-271.

Boddewyn, J. J., \& Brewer, T. L. (1994). International-business political behavior: New theoretical directions. Academy of Management Review, 19(1), 119-143.

Bower, J. L. (2001). Not all M\&As are alike - and that matters. Harvard Business Review, March, 92-101

Boyd, B. K., Takacs, H. K., Hitt, M. A., Bergh, D. D., \& Ketchen, D. J. (2012). Contingency hypotheses in strategic management research: Use, disuse, or misuse? Journal of Management, 38(1), 278-313.

Bremmer, I. (2014). The new rules of globalization. Harvard Business Review, JanuaryFebruary, 103-107.

Brienen, M., Burger, M., \& van Oort, F. (2010). The geography of Chinese and Indian greenfield investments in Europe. Eurasian Geography E Economics, 51, 254-273.

Brouthers, K., Brouthers, L., \& Werner, S. (2008). Real options, international entry mode choice and performance. Journal of Management Studies, 45, 936-960.

Buckley, P., Clegg, L., Cross, A., Liu, X., Cross, H., \& Zheng, P. (2007). The determinants of Chinese outward foreign direct investment. Journal of International Business Studies, 38, 499-518.

Buckley, P., Elia, S., \& Kafouros, M. (2014). Acquisitions by emerging market multinationals: Implications for firm performance. Journal of World Business (in press).

Buckley, P., Forsans, N., \& Munjal, S. (2012). Host-home country linkages and hosthome country specific advantages as determinants of foreign acquisitions by Indian firms. International Business Review, 21, 878-890.

Casciaro, T., \& Piskorski, M. (2005). Power imbalance, mutual dependence, and constraint absorption: A closer look at resource dependence theory. Administrative Science Quarterly, 50, 167-199.

Chen, V., Li, J., \& Shapiro, D. (2012). International reverse spillover effect on parent firms: Evidence from emerging market MNEs in developed markets. European Management Journal, 30, 204-218.

Chen, Y., \& Young, M. (2010). Cross-border mergers and acquisitions by Chinese listed companies: A principal-principal perspective. Asia Pacific Journal of Management, 27, 523-539.
Cheung, Y., \& Qian, X. (2009). Empirics of China's outward direct investment. Pacific Economic Review, 14, 312-341.

Child, J. (2009). Context, comparison and methodology in Chinese management research. Management and Organization Review, 5(1), 91-105.

Child, J., \& Rodriguez, S. B. (2005). The internationalization of Chinese firms: A case for theoretical extension. Management and Organization Review, 1(3), 381-410.

Connelly, B., Tihanyi, L., Certo, S., \& Hitt, M. (2010). Marching to the beat of different drummers: The influence of institutional owners on competitive actions. Academy of Management Journal, 53(4), 723-742.

Das, T. K., \& Teng, B. (2001). Trust, control, and risk in strategic alliance: An integrated framework. Organization Studies, 22(2), 251-283.

Davis, G. F., \& Cobb, J. A. (2010). Resource dependence theory: Past and future. In F. Dobbin \& C. B. Schoonhoven (Eds.), Stanford's organization theory renaissance, 1970 2000 (pp. 21-42). Bingley, NY: Emerald Group.

De Beule, F., \& Duanmu, J. (2012). Locational determinants of internationalization: A firm-level analysis of Chinese and Indian acquisitions. European Management Journal, 30(3), 264-277.

Deng, P. (2009). Why do Chinese firms tend to acquire strategic assets in international expansion? Journal of World Business, 44, 74-84.

Deng, P. (2012). The internationalization of Chinese firms: A critical review and future research. International Journal of Management Reviews, 14(4), 408-427.

Deng, P. (2013). Chinese outward direct investment research: Theoretical integration and recommendations. Management and Organization Review, 9(3), 513-539.

Di Giovanni, J. (2005). What drives capital flows? The case of cross-border M\&A activity and financial economies. Economic Systems, 28, 281-300.

Dikova, D., Rao, S., \& van Witteloostuijn, A. (2010). Cross-border acquisitions abandonment and completion. Journal of International Business Studies, 41(2), 223-245.

DiMaggio, P. J., \& Powell, W. W. (1983). The iron cage revisited: Institutional isomorphism and collective rationality in organizational fields. American Sociological Review, 48, 147-160.

Dress, J., \& Heugens, P. (2013). Synthesizing and extending resource dependence theory: A meta-analysis. Journal of Management, 39(6), 1666-1668.

Duanmu, J. (2012). Firm heterogeneity and location choice of Chinese multinational enterprises. Journal of World Business, 47, 64-72

Dunning, J. (1995). Multinational enterprise and the global economy. New York: AddisonWesley.

Dunning, J. (2009). Location and the multinational enterprise: A neglected factor? Journal of International Business Studies, 40, 5-19.

Finkelstein, S. (1997). Interindustry merger patterns and resource dependence: A replication and extension of Pfeffer (1972). Strategic Management Journal, 18(10), 787-810.

Gaffney, N., Kedia, B., \& Clampit, J. (2013). A resource dependence perspective of EMNE FDI strategy. International Business Review, 22(6), 1092-1100.

Gaur, A. S., Kumar, V., \& Singh, D. (2014). Institutions, resources, and internationalization of emerging economy firms. Journal of World Business, 49(1), 12-20.

Globerman, S., \& Shapiro, D. (2005). Assessing international mergers and acquisitions as a mode of foreign direct investment. In L. Eden \& W. Dobson (Eds.), Governance, multinationals and growth 2005-New horizons in international business (pp. 68-99). UK and Northampton: Cheltenham.

Greene, W. (2003). Econometric analysis (5th ed.). Upper Saddle River, NJ: Prentice Hall.

Guillen, M. \& Garcia-Canal, E. (2009). The American model of the multinational firm and the new multinationals from emerging economies. Academy of Management Perspectives, 23(2), 23-35.

Haleblian, J., Devers, C., McNamara, G., Carpenter, M., \& Davison, R. (2009). Taking stock of what we know about mergers and acquisitions: A review and research agenda. Journal of Management, 35, 469-502.

Heeley, M. B., King, D., \& Covin, J. (2006). Effects of firm R\&D investment and environment on acquisition likelihood. Journal of Management Studies, 43, 15131535.

Hilbe, J. M. (2007). Negative binomial regression. Cambridge, UK: Cambridge University Press.

Hillman, A., Keim, G., \& Schuler, D. (2004). Corporate political activity: A review and research agenda. Journal of Management, 30, 837-857.

Hillman, A., Withers, M., \& Collins, B. (2009). Resource dependence theory: A review. Journal of Management, 35, 1404-1427.

Hoskisson, R. E., Wright, M., Filatotchev, I., \& Peng, M. M. (2013). Emerging multinationals from mid-range economies: The influence of institutions and factor markets. Journal of Management Studies, 50(7), 1295-1321.

Hur, J., Parinduri, R., \& Riyanto, Y. (2011). Cross-border M\&A inflows and quality of country governance: Developing versus developed countries. Pacific Economic Review, 16, 638-655.

Hurst, L. (2011). Comparative analysis of the determinants of China's state-owned outward direct investment in OECD and non-OECD countries. China \& World Economy, 19, 74-91.

Jain, N., Hausknecht, D., \& Mukherjee, D. (2013). Location determinants for emerging market firms. Management Decision, 51(2), 396-418.

Jullens, J. (2013). How emerging giants can take on the world. Harvard Business Review, December, 121-125.

Kamaly, A. (2007). Trends and determinants of mergers and acquisitions in developing countries in 1990. International Research Journal of Finance and Economics, $8,16 \mathrm{~L} 30$.

Kang, Y., \& Jiang, F. (2012). FDI location choice of Chinese multinationals in east and southeast Asia: Traditional economic factors and institutional perspective. Journal of World Business, 47, 45-53.

Karney, C. (2012). Emerging markets research: Trends, issues and future directions. Emerging Markets Review, 13, 159-183. 
Kaufmann, D., Kraay, A., \& Mastruzzi, M. (2010). The worldwide governance indicators: Methodology and analytical issues. Retrieved from http://info.worldbank.org/governance/wgi

Kogut, B., \& Singh, H. (1988). The effect of national culture on the choice of entry mode. Journal of International Business Studies, 19, 411-432.

Kolstad, I., \& Wiig, A. (2012). What determines Chinese outward FDI? Journal of World Business, 47, 26-34.

Kothari, T., Kotabe, M., \& Murphy, P. (2013). Rules of the games for emerging market multinational companies from China and India. Journal of International Management, 19, 276-299.

Kumarasamy, A., Mudambi, R., Saranga, H., \& Tripathy, A. (2012). Catch-up strategies in the Indian auto components industry: Domestic firms' response to market liberalization. Journal of International Business Studies, 43(4), 368-395.

Kutner, M., Nachtsheim, C., \& Neter, J. (2004). Applied linear regression models (4th ed.). McGraw-Hill Irwin.

Kyrkilis, D., \& Pantelidis, P. (2003). Macroeconomic determinants of outward foreign direct investment. International Journal of Social Economics, 30, 827-836.

Lin, Z., Peng, M. W., Yang, H., \& Sun, S. L. (2009). How do networks and learning drive M\&As? An institutional comparison between China and the United States. Strategic Management Journal, 30, 1113-1132.

Luo, Y., \& Tung, R. (2007). International expansion of emerging market enterprises: A springboard perspective. Journal of International Business Studies, 38, 481-498.

Luo, Y., \& Wang, S. (2012). Foreign direct investment strategies by developing country multinationals: A diagnostic model for home country effects. Global Strategy Journal, 2, 244-261.

Matsusaka, J. G. (1996). Did tough antitrust enforcement cause the diversification of American corporations? Journal of Financial Quantitative Analysis, 31, 283-294.

Morck, R., Yeung, B., \& Zhao, M. (2008). Perspectives on China's outward foreign direct investment. Journal of International Business Studies, 39(3), 337-350.

Nicholson, R., \& Salaber, J. (2013). The motives and performance of cross-border acquirers from emerging economies: Comparison between Chinese and Indian firms. International Business Review, 22, 963-980.

Oliver, C. (1990). Determinants of interorganizational relationships: Integration and future directions. Academy of Management Review, 15, 241-265.

Pant, A., \& Ramachandran, J. (2012). Legitimacy beyond borders: Indian software services firms in the United States, 1984 to 2004. Global Strategy Journal, 2, 224-243.

Peng, M. W. (2012). The global strategy of emerging multinationals from China. Global Strategy Journal, 2(2), 97-107.

Peng, M. W., Wang, D. Y., \& Jiang, Y. (2008). An institution-based view of international business strategy: A focus on emerging economies. Journal of International Business Studies, 39, 920-936.

Penner-Hahn, J., \& Shaver, J. (2005). Does international research and development increase patent output? An analysis of Japanese pharmaceutical firms. Strategic Management Journal, 26(2), 121-140.

Pfeffer, J. (1987). A resource dependence perspective on interorganizational relations. In M. Mizruchi \& M. Schwartz (Eds.), Intercorporate relations: The structural analysis of business (pp. 22-55). Cambridge, UK: Cambridge University Press.

Pfeffer, J., \& Salancik, G. (1978). The external control of organizations: A resource dependence perspective. New York, NY: Harper \& Row.

Pfeffer, J., \& Salancik, G. (2003). The external control of organizations: A resource dependence perspective (2nd ed.). Standard, CA: Stanford University Press.

Pollock, T., Chen, C., Jackson, R., \& Hambrick, D. (2010). How much prestige is enough? Assessing the value of multiple types of high-status affiliates for young firms. Journal of Business Venturing, 25, 6-23.
Rabbiosi, L., Stefano, E., \& Bertoni, F. (2012). Acquisitions by EMNCs in developed markets: An organizational learning perspective. Management International Review, 52, 193-212.

Ramasamy, B., Yeung, M., \& Laforet, S. (2012). China's outward foreign direct investment: Location choice and firm ownership. Journal of World Business, $47,17-25$.

Santos, F. M., \& Eisenhardt, K. M. (2005). Organizational boundaries and theories of organization. Organization Science, 16, 491-508.

Shapiro, D. M. (2010). A tribute to Oliver Williamson: Antitrust economics. California Management Review, 52, 137-146.

Sherer, P., \& Lee, K. (2002). Institutional change in large law firms: A resource dependency and institutional perspective. Academy of Management Journal, 45(1), 102-119.

Shimizu, K., Hitt, M., Vaidyanath, D., \& Pisano, V. (2004). Theoretical foundations of cross-border mergers and acquisitions. Journal of International Management, 10, 307-353.

Stucchi, T. (2012). Emerging market firms' acquisitions in advanced markets: Matching strategy with resource-, institution- and industry-based antecedents. European Management Journal, 30, 278-289.

$\mathrm{Su}, \mathrm{N}$. (2013). Internationalization strategies of Chinese IT service suppliers. MIS Quarterly, 37(1), 175-200.

Sun, S. L., Peng, M., Ren, B., \& Yan, D. (2012). A comparative ownership advantage framework for cross-border M\&As: The rise of Chinese and Indian MNEs. Journal of World Business, 47(1), 4-16.

Tolentino, P. (2010). Home country macroeconomic factors and outward FDI of China and India. Journal of International Management, 16, 102-120.

Tsui, A. S. (2004). Contributing to global management knowledge: A case for high quality indigenous research. Asia Pacific Journal of Management, 21, 491-513.

UNCTAD (2014). World investment report 2014: Investing in the SDG: An action plan. New York, Geneva: UNCTAD.

Vuong, Q. (1989). Likelihood ratio tests for model selection and non-nested hypotheses. Econometrica, 57(2), 307-333.

Wang, C., Hong, J., Kafouros, M., \& Boateng, A. (2012). What drives outward FDI of Chinese firms? Testing the explanatory power of three theoretical frameworks. International Business Review, 21, 425-438.

Williamson, O. E. (1991). Comparative economic organization: The analysis of discrete structural alternatives. Administrative Science Ouarterly, 36, 269-296.

Witt, M. A., \& Lewin, A. (2007). Outward foreign direct investment as escape response to home country institutional constraints. Journal of International Business Studies, 38(4), 579-594.

World Bank Database. (2013). Retrieved from http://info.worldbank.org/governance/ wgi/index.asp

Xia, J., Ma, X., Lu, J., \& Liu, D. W. (2013). Outward foreign direct investment by emerging market firms. A resource dependence logic. Strategic Management Journal, 50(7) $1322-1346$.

Xu, D., \& Meyer, K. E. (2013). Linking theory and context: 'Strategy research in emerging economies' after Wright et al. (2005). Journal of Management Studies, 50(7), $1322-1346$

Yang, M. (2012). Outward foreign direct investment activities and strategies by firms from emerging markets: Management literature review from 2005-2010. Current Topics in Management, 16(1), 143-166.

Zhang, J., Zhou, C., \& Ebbers, H. (2011). Completion of Chinese overseas acquisitions: Institutional perspectives and evidence. International Business Review, 20(2), $226-238$ 